\title{
The Hair Cell $\alpha 9 \alpha 10$ Nicotinic Acetylcholine Receptor: Odd Cousin in an Old Family
}

\author{
Marcela Lipovsek ${ }^{1 *}$, Irina Marcovich ${ }^{2}$ and Ana Belén Elgoyhen ${ }^{3 *}$ \\ ${ }^{1}$ Ear Institute, Faculty of Brain Sciences, University College London, London, United Kingdom, ${ }^{2}$ Departments of \\ Otolaryngology \& Neurology, Boston Children's Hospital, Harvard Medical School, Boston, MA, United States, ${ }^{3}$ Instituto de \\ Investigaciones en Ingeniería Genética y Biología Molecular "Dr. Héctor N. Torres" (INGEBI), Consejo Nacional de \\ Investigaciones Científicas y Técnicas (CONICET), Buenos Aires, Argentina
}

\section{OPEN ACCESS}

Edited by:

Barbara Jane Morley,

Boys Town National Research Hospital, United States

Reviewed by: Uwe Maskos, Institut Pasteur, France

Ursula H. Winzer-Serhan, Texas A\&M Health Science Center, United States

*Correspondence: Ana Belén Elgoyhen elgoyhen@dna.uba.ar Marcela Lipovsek m.lipovsek@ucl.ac.uk

Specialty section:

This article was submitted to

Cellular Neurophysiology,

a section of the journal

Frontiers in Cellular Neuroscience

Received: 28 September 2021

Accepted: 25 October 2021

Published: 15 November 2021

Citation:

Lipovsek M, Marcovich I and Elgoyhen AB (2021) The Hair Cell $\alpha 9 \alpha 10$ Nicotinic Acetylcholine Receptor: Odd Cousin in an Old

Family.

Front. Cell. Neurosci. 15:785265. doi: 10.3389/fncel.2021.785265
Nicotinic acetylcholine receptors (nAChRs) are a subfamily of pentameric ligand-gated ion channels with members identified in most eumetazoan clades. In vertebrates, they are divided into three subgroups, according to their main tissue of expression: neuronal, muscle and hair cell nAChRs. Each receptor subtype is composed of different subunits, encoded by paralogous genes. The latest to be identified are the $\alpha 9$ and a10 subunits, expressed in the mechanosensory hair cells of the inner ear and the lateral line, where they mediate efferent modulation. $\alpha 9 \alpha 10$ nAChRs are the most divergent amongst all nicotinic receptors, showing marked differences in their degree of sequence conservation, their expression pattern, their subunit co-assembly rules and, most importantly, their functional properties. Here, we review recent advances in the understanding of the structure and evolution of nAChRs. We discuss the functional consequences of sequence divergence and conservation, with special emphasis on the hair cell $\alpha 9 \alpha 10$ receptor, a seemingly distant cousin of neuronal and muscle nicotinic receptors. Finally, we highlight potential links between the evolution of the octavolateral system and the extreme divergence of vertebrate $\alpha 9 \alpha 10$ receptors.

Keywords: nicotinic acetylcholine receptors, evolution, hair cells, efferent system, ion channel

\section{INTRODUCTION}

Ion channels play a myriad of functions in all domains of life. The different ion channels have evolved over billions of years, rendering an astounding spectrum of families with a wide number of members. Within the ion channels gated by the binding of ligands, the superfamily of pentameric ligand-gated ion channels (pLGICs) is the largest and most functionally diverse (Corringer et al., 2012; Jaiteh et al., 2016). pLGICs are ubiquitous in the major taxonomic groups, except multicellular plants and fungi (Jaiteh et al., 2016). The more recent discovery of pLGICs in bacterial species and Archaea has shown a striking conservation of many structural features within the entire family, even between distant prokaryotic and eukaryotic members (Tasneem et al., 2005; Bocquet et al., 2007), indicating an ancient origin for this receptor family (Jaiteh et al., 2016). The functional roles of pLGICs have been more thoroughly described in animals with bilateral symmetry (Bilateria), where they mediate fast synaptic transmission in the nervous system. In vertebrates, pLGICs are represented by the Cys-loop family and include the nicotinic acetylcholine receptors (nAChRs), serotonin type 3 receptors $\left(5-\mathrm{HT}_{3}\right)$, gamma aminobutyric acid type A receptors $\left(\mathrm{GABA}_{\mathrm{A}}\right)$ and glycine receptors (Karlin and Akabas, 1995; Corringer et al., 2012; Jaiteh et al., 2016). 

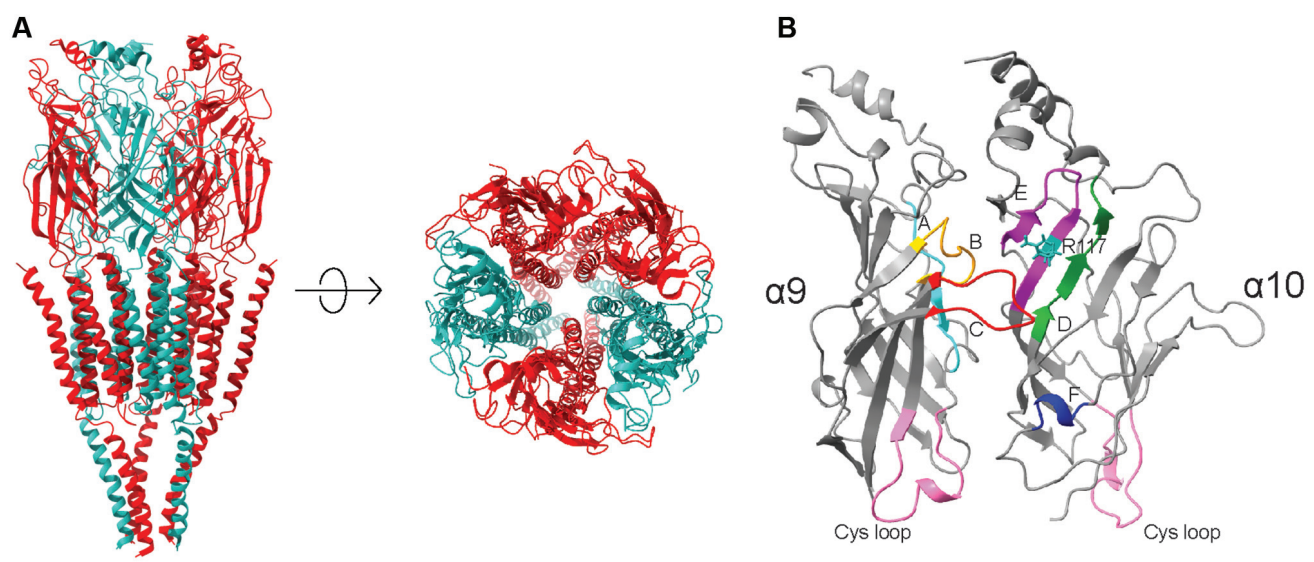

FIGURE 1 | (A) Ribbon structure of a pentameric nicotinic acetylcholine receptor, showing the arrangement of subunits around the channel pore. (B) Detailed view of the ligand binding site of an $\alpha 9 \alpha 10$ nAChRs receptor. The locations of the conserved loops that contribute to the binding site are highlighted in colour. The Cys-loops are highlighted in pink.

\section{PENTAMERIC LIGAND-GATED ION CHANNELS: STRUCTURE AND EVOLUTION}

Pentameric ligand-gated ion channels of eukaryotes and prokaryotes exhibit relatively low amino acid sequence identity (18\%-20\%), but they share key common structural features. Receptor subunits have a similar domain organization and transmembrane topology, with motifs that are conserved in the entire family across species and are necessary for receptor function (Tasneem et al., 2005; Bocquet et al., 2007; Corringer et al., 2012; Jaiteh et al., 2016). Numerous 3D crystallographic or electron microscopy resolution structures of both prokaryotic (Hilf and Dutzler, 2008, 2009; Bocquet et al., 2009) and eukaryotic (Unwin, 1995, 2005; Miyazawa et al., 2003; Hibbs and Gouaux, 2011; Althoff et al., 2014; Hassaine et al., 2014; Miller and Aricescu, 2014; Du et al., 2015; Morales-Perez et al., 2016) pLGICs show a similar fivefold symmetrical arrangement of subunits around a central pore, with defined extracellular and transmembrane (TM) domains (Figure 1A). The extracellular domain folds into a highly conserved immunoglobulin-like $\beta$-sandwich (which includes $10 \beta$-sheets) and contains the orthosteric ligand binding sites. The TM domain consists of four $\alpha$-helices, with TM2 lining the channel pore, surrounded by a ring made of TM1 and TM $3 \alpha$-helices. TM4 is the most peripheral helix and it interacts with the membrane lipid bilayer (Karlin, 2002; Corringer et al., 2012). The conserved 3D structure of all pLGICs supports a common phylogenetic origin for the evolutionary distant eukaryote and prokaryote pentameric receptors. Moreover, a proline residue in the extracellular domain at the loop connecting the $\beta 6$ and $\beta 7$ strands has been under strong selective pressure, is conserved in all pLGICs and is the basis for the proposal to name this family as the "Pro-Loop" receptors (Jaiteh et al., 2016).

Pentameric ligand-gated ion channels are ubiquitous in the major taxonomic groups except multicellular plants and fungi.
Although pLGICs were first identified in vertebrates (Noda et al., 1982) and described as Cys-loop receptors due to the presence of a cysteine disulfide bridge that stabilizes the $\beta 6-\beta 7$ loop in the N-terminal extracellular domain, the discovery of Cys-less members indicates that this is not a plesiomorphic characteristic of the entire superfamily (Jaiteh et al., 2016). The residues most prominently conserved across the entire superfamily, including the proline residue mentioned above, participate in the interactions between the extracellular and TM domains crucial for signal transduction during channel opening (Jaiteh et al., 2016).

Cys-less pLGICs are present in Bacteria and Archaea and unicellular eukaryotes. Among Eumetazoans, Cys-less pLGICs have been identified in cnidarians (e.g., polyps and jellyfish), echinoderms (e.g., starfish and sea urchins), nematodes (e.g., roundworms), platyhelminths (e.g., flatworms), annelids (e.g., earthworms), and molluscs (e.g., snails, octopus and clams). They are absent from vertebrates and only found in a cephalochordate (e.g., lancelet) and a tunicate (e.g., sea squirts; Jaiteh et al., 2016).

Evolutionary analysis suggests that Cys-loop pLGICs are only present in eukaryotes and form a monophyletic group, originating from a single ancestor gene. This later diverged, generating the extant complement of subunits, which includes a subdivision into anionic and cationic receptors, that predates the origin of metazoans (Jaiteh et al., 2016).

\section{Cys-LOOP RECEPTORS}

In Bilateria, pLGICs are most prominently represented by the family of Cys-loop receptors, with all member subunits containing a disulfide cysteine bridge which closes a $\beta 6-\beta 7$ loop comprising 13 amino acids (Changeux et al., 1987; Maricq et al., 1991; Corringer et al., 2012; Smart and Stephenson, 2019). Based on mutagenesis studies, this cysteine bridge has been proposed to be essential for the correct folding and assembly of Cys-loop receptors (Mishina et al., 1985; Blount and Merlie, 
1990; Rajendra et al., 1995). Vertebrate Cys-loop receptors are divided into two subfamilies: the cationic nAChRs and $5-\mathrm{HT}_{3}$ receptors and the anionic $\mathrm{GABA}_{\mathrm{A}}$ and glycine receptors, which serve excitatory and inhibitory synaptic transmission in the nervous system, respectively (Nemecz et al., 2016). The Cys-loop family also includes zinc-gated channels that are absent in some mammalian species, and whose function is still not well understood (Davies et al., 2003). Both nAChRs and GABA receptors are composed of a wide array of subunits, leading to a wide range of possible pentameric combinatorial assemblies. On the other hand, vertebrate genomes contain genes coding for only five subunits of $5-\mathrm{HT}_{3}$ receptors and five subunits of glycine receptors, leading to a more limited number of possible combinatorial assemblies (Nemecz et al., 2016).

In serotonin-gated Cys-loop receptors, $5-\mathrm{HT}_{3} \mathrm{~A}$ is the only subunit that assembles into homomeric receptors. Functional diversity is achieved by the co-assembly of $5-\mathrm{HT}_{3} \mathrm{~A}$ with either $5-\mathrm{HT}_{3} \mathrm{~B}, \mathrm{C}, \mathrm{D}$, or $\mathrm{E}$ in heteromeric combinations (Niesler et al., 2007; Barnes et al., 2009; Holbrook et al., 2009). Moreover, diversity is further increased by alternative splicing of the genes encoding the 5- $\mathrm{HTR}_{3} \mathrm{~A}$ and $\mathrm{E}$ subunits (Brüss et al., 2000; Niesler, 2011). Functional glycine receptors are either homopentamers of $\alpha$ subunits, or heteropentamers composed of two $\alpha$ and three $\beta$ subunits (Betz and Laube, 2006). Four $\alpha$ subunits $(\alpha 1-\alpha 4)$ and one $\beta$ subunit have been identified. Further diversity arises from the alternative splicing of $\alpha 1$ ( $\alpha 1^{\mathrm{INS}}$ and $\left.\alpha 1^{\mathrm{del}}\right), \alpha 2(\alpha 2 \mathrm{~A}$ and $\alpha 2 \mathrm{~B})$, $\alpha 3(\alpha 3 S$ and $\alpha 3 \mathrm{~L})$ and $\beta(\beta \Delta 7)$ subunits and by mRNA editing of the $\alpha 2$ and $\alpha 3$ subunits (Meier et al., 2005; Betz and Laube, 2006; Oertel et al., 2007).

GABA is the main inhibitory neurotransmitter in the mammalian nervous system, where $19 \mathrm{GABA}_{\mathrm{A}}$ receptor subunits have been identified (Simon et al., 2004; Amundarain et al., 2019; Smart and Stephenson, 2019). The subunits are divided into classes $(\alpha, \beta, \gamma, \rho, \theta, \varepsilon, \pi$, and $\delta)$ and subclasses $(\alpha 1-6, \beta 1-3$, $\gamma 1-3$, and $\rho 1-3)$, based on sequence identity. The diversity of subunits is further increased by alternative splicing, to which 9 out of 19 subunits are subject to, and is proposed to regulate subunit expression (Whiting et al., 1990; Simon et al., 2004). The amino acid sequence identity between subunits of the same class ranges between 70 and $80 \%$ and falls to $30-40 \%$ for subunits of different classes (Macdonald and Olsen, 1994). Individual subunits exhibit distinct but overlapping and often widespread expression patterns throughout the nervous system (Pirker et al., 2000 ), resulting in a large variety of $\mathrm{GABA}_{\mathrm{A}}$ receptor subtypes in the brain. Native $\mathrm{GABA}_{\mathrm{A}}$ receptors are mainly composed of $\alpha \beta \gamma$ subunits usually in a stoichiometry of 2:2:1 with identical (but not always) $\alpha$ and $\beta$ subunits (Olsen and Sieghart, 2008; Sarto-Jackson and Sieghart, 2008; Amundarain et al., 2019; Smart and Stephenson, 2019). However, other stoichiometries can be observed. Thus, $\varepsilon, \pi$ and $\delta$ subunits can replace the $\gamma$ subunit, and a $\theta$ subunit can replace a $\beta$ subunit. The $\rho 1 / 2 / 3$ subunits usually assemble in homopentamers or heteropentamers (Cutting et al., 1991; Enz and Cutting, 1998). However, the assembly of $\rho$ subunits with $\alpha 1$ and/or $\gamma 2$ subunits has been also identified (Milligan et al., 2004; Harvey et al., 2006). Although initially described as retinal subunits, the $\rho$ subunits are also expressed in the brain (Milligan et al., 2004; Harvey et al., 2006).
Neurons co-express multiple $\mathrm{GABA}_{\mathrm{A}}$ subunits and a single neuron can express several different receptor subtypes (Olsen and Sieghart, 2008; Sarto-Jackson and Sieghart, 2008; Smart and Stephenson, 2019; Sallard et al., 2021). The most abundant subtype in the mammalian nervous system is $\alpha 1 \beta 2 \gamma 2$ (Rudolph and Knoflach, 2011). Currently, eleven native $\mathrm{GABA}_{\mathrm{A}}$ receptors have been conclusively identified: $\alpha 1 \beta 2 \gamma 2, \alpha 1 \beta \gamma 2, \alpha 3 \beta \gamma 2, \alpha 4 \beta \gamma 2$, $\alpha 4 \beta 2 \delta, \alpha 4 \beta 3 \delta, \alpha 5 \beta \gamma 2, \alpha 6 \beta \gamma 2, \alpha 6 \beta 2 \delta, \alpha 6 \beta 3 \delta$, and $\rho$. Further combinations are classified with a high probability of assembly and the number of described native $\mathrm{GABA}_{\mathrm{A}}$ receptors continues to increase (Olsen and Sieghart, 2008). The incorporation of different subunits to the pentamer determines the trafficking, cell surface expression, internalisation, and function of $\mathrm{GABA}_{\mathrm{A}}$ receptors (Jacob et al., 2008). For example, receptors that include the $\gamma 2$ subunit (except when associated with $\alpha 5$ ) cluster at the postsynaptic membrane and distribute dynamically between synaptic and extrasynaptic locations, whereas those incorporating the $\delta$ subunit appear to be exclusively extrasynaptic (Jacob et al., 2008).

\section{NICOTINIC ACETYLCHOLINE RECEPTORS}

The nAChRs are a major branch of the Cys-loop family of the pLGIC superfamily (Corringer et al., 2012). Vertebrate nAChRs are non-selective cation channels. To date, 19 different nAChR subunits have been described in most of the main vertebrate clades: $\alpha 1-\alpha 10, \beta 1-\beta 4, \gamma, \delta$, and $\varepsilon$ (Karlin, 2002; Corringer et al., 2012), with $\alpha 11$ and $\beta 5$ subunits only identified in some fish species (Pedersen et al., 2019). The nAChR subunits were initially classified into muscle and neuronal subtypes, based on their expression pattern and function, either at the neuromuscular junction or the nervous system (Karlin, 2002; Changeux et al., 1987; Le Novere and Changeux, 1995). However, this dichotomic classification required revisiting with the discovery of the hair cell nAChR subunits.

Functional nAChRs result from the assembly of either five identical or different subunits, giving rise to homomeric or heteromeric pentamers, respectively (Karlin, 2002). With the exception of $\alpha 9$ homomeric and $\alpha 9 \alpha 10$ heteromeric receptors (Elgoyhen et al., 1994, 2001), all nAChR known to date respond to nicotine, thus naming the subfamily. The ligand binding site is at the interface of the extracellular domains of adjacent subunits and is formed by six structurally conserved loops (Figure 1B). Each binding site is composed of a principal component or (+) face provided by one subunit, which contributes three loops of highly conserved residues (loops A-C), and a complementary component, or (-) face, of the adjacent subunit, which contributes the reminder less conserved loops (loops D-F; Brejc et al., 2001; Unwin, 2005; Dellisanti et al., 2007). Consequently, the components of the extracellular inter-subunit binding sites are non-equivalent and their loops contribute differentially to receptor function (Karlin, 2002).

The rules that govern the combinatorial assembly of functional $\mathrm{nAChRs}$ are for the most part unknown, especially in the case of neuronal receptors. These are formed by diverse combinations of $\alpha 2-\alpha 7$ ( $\alpha 8$ in non-mammals) and $\beta 2-4$ subunits, giving rise to an extensive range of as yet not fully characterised 
combinatorial arrangements (Gotti et al., 2009; Zoli et al., 2015, 2018). This complexity is further extended by the combinatorial assembly of heteromeric neuronal receptors formed by the same subunits, but with alternative stoichiometry (Nelson et al., 2003; Moroni and Bermudez, 2006; Moroni et al., 2006; Krashia et al., 2010; Benallegue et al., 2013; Mazzaferro et al., 2017). In contrast, muscle receptors show a more constrained co-assembly spectrum, since they are formed by $\alpha 1_{2} \beta 1 \gamma$, and $\delta$, or, $\varepsilon$ and do not co-assemble with non-muscle subunits (Mishina et al., 1986; Cetin et al., 2020). Finally, nAChR subunits expressed in cochlear and vestibular hair cells have a very strict co-assembly pattern, only comprised of $\alpha 9$ and $\alpha 10$ subunits (Elgoyhen et al., 1994, 2001; Sgard et al., 2002). While $\alpha 9$ subunits can assemble into functional homomeric receptors when expressed in heterologous systems (Elgoyhen et al., 1994), these do not play a major role in inner ear hair cells in vivo, as described in mice lacking the CHRNA10 gene, coding for the $\alpha 10$ subunit (Vetter et al., 2007). More importantly, neither $\alpha 9$ nor $\alpha 10$ subunits co-assemble with other nAChR subunits to form functional receptors (Elgoyhen et al., 1994; Scheffer et al., 2007). Therefore, the $\alpha 9$ and $\alpha 10$ subunits are functionally isolated from the remainder nicotinic subunits. Resulting from their expression pattern (Elgoyhen et al., 1994; Morley et al., 1998, 2018; Atlas, 2013), their distinct evolutionary trajectory when compared to other nAChRs (Franchini and Elgoyhen, 2006; Lipovsek et al., 2012; Marcovich et al., 2020), their lack of assembly with other nAChR subunits (Elgoyhen et al., 1994; Scheffer et al., 2007), and their peculiar pharmacological and biophysical properties (Elgoyhen et al., 1994, 2001; Rothlin et al., 1999, 2003; Verbitsky et al., 2000; Sgard et al., 2002; Gomez-Casati et al., 2005; Plazas et al., 2007), $\alpha 9$ and $\alpha 10$ form a separate branch within the subfamily of nAChRs. Thus, although initially included within the neuronal subgroup of $\mathrm{nAChR}$ subunits (Karlin, 2002), $\alpha 9$ and $\alpha 10$ subunits do not fully share functional, expression, pharmacological and evolutionary properties with neuronal subunits, and are therefore clearly non-neuronal. We propose to re-classify them as "hair cell" nAChR subunits, based on their known function mediating efferent olivocochlear inhibition of inner ear hair cells (Katz et al., 2004; Ballestero et al., 2011; Elgoyhen and Katz, 2012; Katz and Elgoyhen, 2014).

A consequence of the differences in co-assembly rules between the three subgroups of nAChRs is that muscle cells mainly express two receptor variants (one adult and one embryonic; Mishina et al., 1986), cochlear hair cells only one (Elgoyhen et al., 1994, 2001; Morley et al., 1998; Vetter et al., 1999, 2007; Gomez-Casati et al., 2005), while neurons are capable of expressing a great diversity of nAChRs (Zoli et al., 2015, 2018; Marcovich et al., 2020). For example, $\alpha 7^{\star}$ (*, subunit containing) and $\alpha 4 \beta 2^{*}$ are the two most abundant nAChRs in the central nervous system (Zoli et al., 2015, 2018), whereas receptors containing $\alpha 3$ and $\beta 4$ subunits mediate fast synaptic transmission at the autonomic ganglia (Covernton et al., 1994; Skok, 2002) and $\alpha 6 \beta 2^{\star}$ receptors are localised presynaptically in both visual and mesostriatal pathways (Gotti et al., 2009). Moreover, neuronal receptors can contain more than two different subunits. For example, $\alpha 4 \beta 2^{*} \mathrm{nAChRs}$ in some brain regions also contain the $\alpha 5$ subunit (Brown et al., 2007). For a comprehensive list of experimentally validated $\mathrm{nAChR}$ assemblies see Supplementary Table S6 in Marcovich et al. (2020).

A recent systematic gene expression re-analysis of 10 single-cell transcriptomic studies extended to the single cell level the identification of the variety of possible neuronal nAChRs assemblies (Marcovich et al., 2020). This study explored the potential spectrum of $\mathrm{nAChRs}$ in any given neuron with diverse neurochemical identities in different regions of the mouse nervous system. In doing so it outlined the potential complement of pentameric receptors present in each cell type, by identifying the subunit combinations that are present within a 10 -fold, 100 -fold or 1,000-fold range of expression level or altogether absent. As expected, neurons express a potentially wide range of neuronal $\mathrm{nAChR}$ variants.

The possibility of toggling between nAChR subunits incorporated into different pentameric assemblies gives rise to receptors with a wide variety of functional properties. Thus, neurons have the potential to express $\mathrm{nAChRs}$ with diverging ACh sensitivity, kinetics, conductance and relative cation permeability (Patrick et al., 1993; Dani and Bertrand, 2007; Zoli et al., 2015, 2018) and consequently adjust their properties to serve differential functions in different regions of the nervous system. For example, receptors composed solely of $\alpha 7$ subunits have low affinity for $\mathrm{ACh}$, fast desensitisation kinetics and high relative calcium permeability (Cooper et al., 1991; Séguéla et al., 1993). Receptors composed of $\alpha 4$ and $\beta 2$ subunits have a higher affinity for ACh, slower desensitisation kinetics, and lower relative calcium permeability (Cooper et al., 1991; Fucile et al., 2006; Dani and Bertrand, 2007). The inclusion of additional subunits into the pentamer also contributes to functional diversity. For instance, the incorporation of the $\alpha 5$ subunit increases the calcium permeability, ACh sensitivity, and desensitization kinetics of $\alpha 4 \beta 2^{*}$ receptors (Tapia et al., 2007; Kuryatov et al., 2008; Sciaccaluga et al., 2015). On the other hand, the incorporation of the $\beta 3$ subunit to $\alpha 4 \beta 2^{\star}$ receptors increases ACh sensitivity, without significantly affecting calcium permeability (Tapia et al., 2007; Kuryatov et al., 2008). Finally, alternative stoichiometries of the same subunit assemblies (e.g., $\alpha 4_{2} \beta 2_{3}$ or $\left.\alpha 4_{3} \beta 2_{2}\right)$ result in receptors with different sensitivity to $\mathrm{ACh}$, unitary current amplitude, desensitization rate, calcium permeability, and selectivity for agonists and antagonists (Nelson et al., 2003; Moroni and Bermudez, 2006; Moroni et al., 2006; Tapia et al., 2007; Krashia et al., 2010; Mazzaferro et al., 2011, 2014, 2017; Benallegue et al., 2013; New et al., 2018), further increasing the extent of functional diversity of neuronal nAChRs.

The analysis of single-cell transcriptomic data revealed that the expression pattern of nicotinic subunits could indeed contribute to functional diversity. For example, cortical neurons that project to both the ventral posteromedial nucleus (VPM) and the posteromedial complex of the thalamus express significantly higher levels of the $\alpha 5$ subunit than neurons only projecting to the VPM, suggesting that the latter could have a lower density of $\alpha 4 \alpha 5 \beta 2^{*}$ compared to $\alpha 4 \beta 2^{*}$ nAChRs. This might relate to the known differences in excitability of layer VI neurons (Landisman and Connors, 2007). In addition, differential co-expression patterns of $\mathrm{nAChR}$ subunits are also observed between four different subtypes of dopaminergic 
neurons in the midbrain ventral tegmental area (VTA). $\beta 2$ and $\beta 3$ subunits are expressed at comparable levels in all four VTA dopaminergic neuron subtypes, lower levels of $\alpha 4$ are present in VTA2 and VTA4, and $\alpha 5$ is absent in VTA3 neurons and expressed at different, but low levels in VTA1, VTA2, and VTA4. These observations suggest that the four subtypes of dopaminergic neurons might contain different levels of $\alpha 4 \beta 2^{\star}, \alpha 4 \alpha 5 \beta 2^{\star}$, and $\alpha 4 \beta 2 \beta 3^{\star}$ receptors. Thus, the differential modulatory control of dopaminergic neuron firing patterns exerted by cholinergic input (Maskos et al., 2005; Mameli-Engvall et al., 2006), might relate to the expression of functionally different neuronal nAChRs.

In contrast to the wide variety of neuronal nAChRs expressed in the nervous system, cochlear and vestibular hair cells only express functional $\alpha 9 \alpha 10 \mathrm{nAChRs}$ (Elgoyhen et al., 1994, 2001; Hiel et al., 1996; Morley et al., 1998; Vetter et al., 1999, 2007; Morley and Simmons, 2002; Sgard et al., 2002). Although several studies have shown expression of $\alpha 1, \beta 2, \beta 4$, and $\gamma$ transcripts (Scheffer et al., 2007; Burns et al., 2015; Cai et al., 2015; Roux et al., 2016; McInturff et al., 2018; Marcovich et al., 2020), no response to nicotine is observed in hair cells (Housley and Ashmore, 1991; Fuchs and Murrow, 1992b; Gomez-Casati et al., 2005; Ballestero et al., 2011), indicating that functional muscle or neuronal nAChRs are not present at the plasma membrane and that the mRNAs detected in hair cells most likely derive from redundant or residual transcription regulation mechanisms. In addition, acetylcholine responses are absent in $\alpha 9$ and $\alpha 10$ knockout mice (Vetter et al., 2007), indicating that only $\alpha 9 \alpha 10$ nAChRs drive cholinergic responses in hair cells and that the lack of CHRNA9 and/or CHRNA10 transcription is not compensated by the expression of either muscle or neuronal $\mathrm{nAChR}$ genes. A striking and unique feature of the $\alpha 9 \alpha 10 \mathrm{nAChR}$ is that, in contrast to all other nAChRs which serve excitatory neurotransmission, it elicits synaptic inhibition of hair cells. This is brought about by the secondary activation of a nearby calcium-dependent SK2 potassium channel which leads to hair cell hyperpolarization (Housley and Ashmore, 1991; Fuchs and Murrow, 1992a; Blanchet et al., 1996; Glowatzki and Fuchs, 2000; Katz et al., 2004; Gomez-Casati et al., 2005; Ballestero et al., 2011; Figure 2).

All components of the cholinergic system, including synthesis and degradation of $\mathrm{ACh}$, have been identified in mammalian non-neuronal cells, including epithelial, endothelial and immune cells (Wessler et al., 1998). Moreover, alteration of the expression of nAChRs has been implicated in autoimmune and inflammatory diseases (Wang et al., 2003; Liu et al., 2017). Nicotinic subunits (such as $\alpha 7, \alpha 9$ and $\alpha 10$ ) and muscarinic ACh receptors, are expressed in peripheral, non-neuronal tissues, including the skin and the immune system where they play an important immunomodulatory role (Arredondo et al., 2002; Wang et al., 2003; Nguyen et al., 2004; Peng et al., 2004; Wessler and Kirkpatrick, 2008; Rosas-Ballina et al., 2011; St-Pierre et al., 2016; Fujii et al., 2017; Liu et al., 2017, 2019; Zakrzewicz et al., 2017; Zhang et al., 2020). Whether nAChRs expressed in non-neuronal tissues signal through channel activation or through alternative metabotropic pathways is still an open question (Valbuena and Lerma, 2016). In any event, during

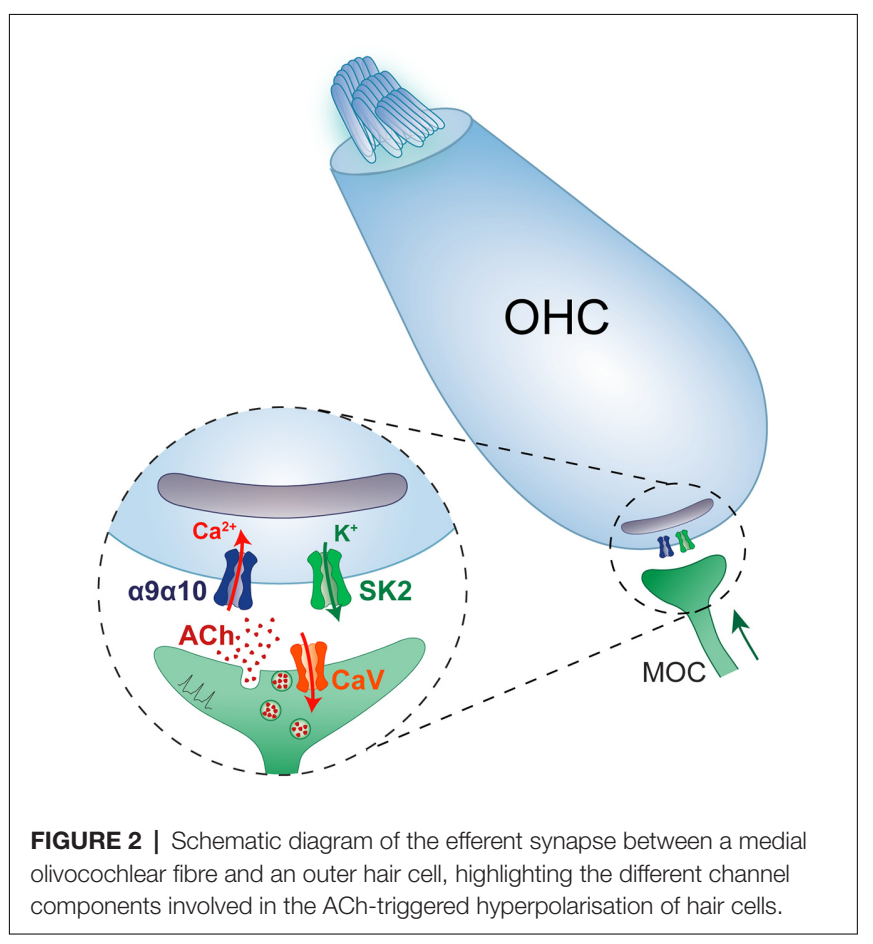

the course of evolution, the autocrine/paracrine effect of ACh could have been served by a multiple and redundant battery of expressed muscarinic and nAChRs. Overall, a potential role for peripheral function as a player in the evolutionary processes that shaped the coding sequence and expression patterns of nicotinic receptors is yet to be explored.

\section{EVOLUTION OF nAChRs}

Numerous phylogenetic analyses of the subfamily of nAChR subunits have been performed (Ortells and Lunt, 1995; Le Novere and Changeux, 1995; Tsunoyama and Gojobori, 1998; Dent, 2006; Franchini and Elgoyhen, 2006; Lipovsek et al., 2012; Li et al., 2016; Faltine-Gonzalez and Layden, 2019; Jiao et al., 2019; Pedersen et al., 2019; Marcovich et al., 2020; Jones et al., 2021). Some of them date to the pre-genomic era, including a small number of coding sequences and leading to less informative iterations of phylogenetic tree topologies. In addition, the long evolutionary distances make the ancestral subunits, from which the entire family of extant $\mathrm{nAChR}$ subunits radiated, difficult to track. One of the first comprehensive analyses of bilaterian pLGIC evolution suggested that the last common ancestor to Bilateria most likely had at least an $\alpha 7$-like subunit, an $\alpha 9$-like subunit, a neuronal/muscle $\alpha$-like subunit and a neuronal/muscle non $\alpha$-like subunit (Dent, 2006). Overall, nAChRs are only found in Eumetazoans, and the addition of new data from cnidarian genomes showed the independent radiation of $\mathrm{nAChR}$ genes in the cnidarian and bilaterian lineages (Faltine-Gonzalez and Layden, 2019; Jiao et al., 2019).

Several difficulties are presented when attempting to establish phylogenetic relationships within radiating protein coding families across long evolutionary distances, and the results 
obtained can vary depending on the methodologies used, the phylogenetic span and the number of sequences analysed. The presence of both a neuronal/muscle-like subunit and an $\alpha 7$ like subunit in the last common ancestor of Bilateria is strongly supported by the clear identification of corresponding groups of subunits in protostomes (Jones and Sattelle, 2004, 2010; Dent, 2006, 2010; Holden-Dye et al., 2013; Faltine-Gonzalez and Layden, 2019; Pedersen et al., 2019), placing the origin of these subunits before the divergence of Bilateria. In contrast, the presence of an $\alpha 9$-like subunit in the last common ancestor of Bilateria is less clear, only weakly supported by one report showing the grouping of annelid subunits on the same branch as the rat $\alpha 9$ subunit (Dent, 2006) and a separate report showing the grouping of a C. elegans subunit (ACR21) with the $\alpha 9 / \alpha 10$ branch (Faltine-Gonzalez and Layden, 2019) although the latter grouping was not observed in the previous analysis performed on smaller datasets that crucially did not include sequences from cnidarian (outgroup to Bilateria) species (Dent, 2006, 2010). Therefore, though there is strong evidence that the last common ancestor of Bilateria most likely already had at least two nAChR subunits (an $\alpha 7$-like and a neuronal/musclelike) the presence of a second neuronal/muscle-like and an $\alpha 9$ like subunits is less well supported by current data. An updated and comprehensive analysis of Eumetazoan nAChR subunits, exploiting the ever-increasing number of new genomes available, will undoubtedly shed light on this issue in the near future.

The likely scenario tracing the evolution of $\mathrm{nAChR}$ subunits in the vertebrate lineage is a lot clearer and has been extensively studied (Le Novere and Changeux, 1995; Ortells and Lunt, 1995; Le Novere et al., 2002; Franchini and Elgoyhen, 2006; Dent, 2010; Elgoyhen and Franchini, 2011; Lipovsek et al., 2012; Pedersen et al., 2019; Marcovich et al., 2020). Making use of sequence phylogeny, exon-intron organization, and chromosomal information for synteny analysis and identification of paralogons, Pedersen et al. (2019) have shown that the last common ancestor of vertebrates had a repertoire of 10 genes coding for $\mathrm{nAChR}$ subunits. They propose that the extant complement of vertebrate subunits resulted from the first and second rounds of tetraploidization which took place in the stem vertebrate branch, between 550 and 500 million years ago, duplicate gene losses and occasional de novo duplications and, in the teleost lineage, a third whole genome duplication. The different extant subunits are therefore encoded by paralogous genes, all proposed to derive from five paralogons (Pedersen et al., 2019).

The analysis of phylogenetic trees constructed using protein coding sequences helps establish the degree of similarity and divergence between paralogous genes. Many such analyses have been performed for nAChR subunits, chiefly including vertebrate sequences. However, as mentioned above, these analyses have caveats and limitations that must be considered when drawing conclusions about the origins and relationships between members of a gene family. Overall, muscle and neuronal (excluding $\alpha 7$-like) subunits show a greater degree of sequence similarity amongst themselves, forming two groups comprised of $\alpha$ and non- $\alpha$ subunits. Also, $\alpha 7$-like subunits typically form their own branch, that may be more similar to the $\alpha 9 / \alpha 10$ subunits
(Nishino et al., 2011; Marcovich et al., 2020) or to the $\alpha /$ non$\alpha$ group (Lipovsek et al., 2012; Pedersen et al., 2019). Finally, $\alpha 9$ and $\alpha 10$ subunits form their own group, in line with their lowest degree of sequence identity when compared against all other nAChR subunits. Of note, the position of the $\alpha 9 / \alpha 10$ group as the outermost branch on the tree of vertebrate nAChR paralogues (although see Figure 3 and Marcovich et al., 2020) has been repeatedly used as evidence for a more ancestral origin of $\alpha 9 / \alpha 10$ subunits, proposing that an $\alpha 9$-like subunit was the first one to split within the subfamily (Ortells and Lunt, 1995; Le Novere and Changeux, 1995; Tsunoyama and Gojobori, 1998; Le Novere et al., 2002). However, it must be pointed out that phylogenetic trees built based on coding sequence alignments merely reflect the degree of sequence identity. Separate branches and/or greater distance metrics could either result from: (1) the slow accumulation of changes through longer evolutionary times; (2) the rapid accumulation of sequence changes along shorter evolutionary times; or (3) a combination of both. The observation of higher-than-expected rates of non-synonymous substitutions (Franchini and Elgoyhen, 2006; Lipovsek et al., 2014; Pedersen et al., 2019), strong signals of positive selection (Franchini and Elgoyhen, 2006; Marcovich et al., 2020) and higher rates of site-specific evolutionary shifts in the amino acid biochemical state in the genes coding for $\alpha 9$ and $\alpha 10$ subunits (Marcovich et al., 2020) support the second scenario. In summary, although the $\alpha 9$ and $\alpha 10$ subunits are categorically the most divergent amongst the repertoire of vertebrate nAChR subunits, more evidence is required to establish whether they were the first branch to split from the ancestral nicotinic subunit of Bilateria (or Metazoa). As discussed above, this scenario is not currently supported, due to the lack of unequivocally identified $\alpha 9$-like subunits in protostomes. Once again, further analysis of newly available genomes covering all branches of Bilateria and, more importantly, outgroups such us Cnidarians, will contribute to addressing this question. Moreover, coding sequence-based analysis can be complemented by studying other aspects of gene and genome architecture (e.g., intron-exon structure, synteny, promoter/enhancer sequences), alongside analysis on the conservation and divergence of protein assembly and functional properties.

Finally, with the exception of the loss of the $\alpha 7$-like $\alpha 8$ subunit in mammals (Dent, 2006, 2010; Marcovich et al., 2020), the same repertoire of paralogous genes coding for $\mathrm{nAChR}$ subunits has been retained across the branch of tetrapod vertebrates. This high level of subunit conservation suggests a family-wide negative selection pressure for the loss of paralog genes. Moreover, it points towards an important functional relevance of each subunit across the clade, that may have greatly influenced their evolutionary history.

\section{EVOLUTION OF NEURONAL nAChRs}

In tetrapods, there are 10 neuronal $\mathrm{nAChR}$ subunits $[\alpha 2-\alpha 8$ $(\alpha 2-\alpha 7$ in mammals) and $\beta 2-\beta 4]$, resulting in a plethora of subunit co-expression patterns and co-assembly possibilities (Marcovich et al., 2020). Due to the widespread expression of neuronal subunits in different regions of the nervous system 


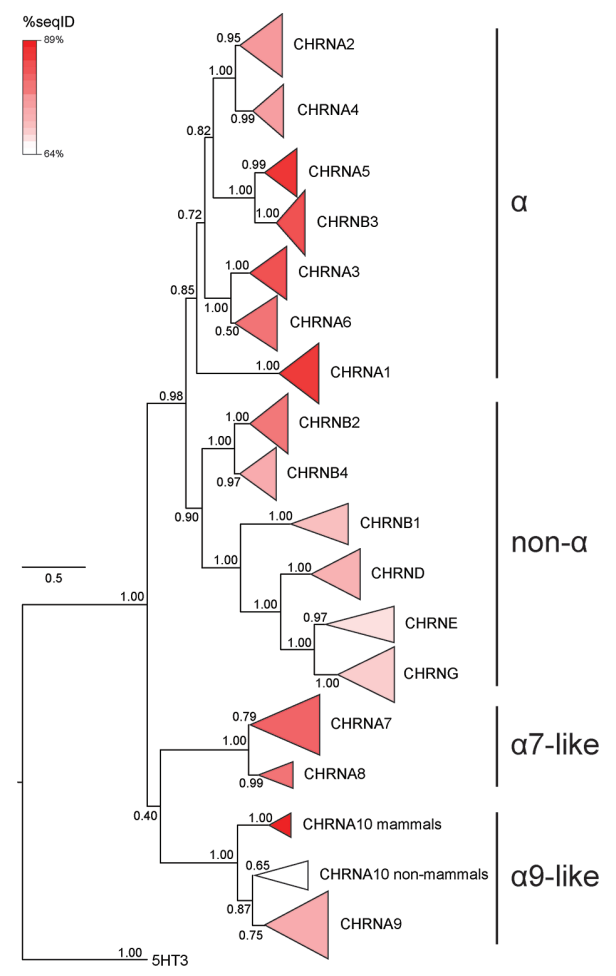

FIGURE 3 | Phylogenetic tree showing the relationships between vertebrate nicotinic subunits. The branches corresponding to the same subunits of different species were collapsed to their respective node. The length of each triangle denotes sequence divergence from the corresponding node. Triangle shades depict the average sequence identity within the branch. Numbers in each branch indicate bootstrap values obtained during phylogeny construction. The scale bar indicates the number of amino acid substitutions per site. Modified from Marcovich et al. (2020), under the Creative Commons license (http://creativecommons.org/licenses/by/4.0/).

and in different neuronal types within a region (Marcovich et al., 2020), randomly acquired coding sequence mutations that lead to changes in functional properties may have had deleterious effects on alternative receptor combinations expressed in different neuronal cell types. Therefore, the coding sequences of neuronal nAChRs were under strong negative selection pressure (Franchini and Elgoyhen, 2006; Elgoyhen and Franchini, 2011; Lipovsek et al., 2012). Moreover, an analysis of site-specific evolutionary shifts in amino acid biochemical state failed to identify between-clade functional divergence at the sequence level on neuronal subunits (Marcovich et al., 2020). This is mirrored by the observation that the biophysical and pharmacological properties of the two most abundant neuronal nAChRs ( $\alpha 4 \beta 2$ and $\alpha 7$ receptors) in three tetrapod species (rat, chicken, and frog) show a high degree of conservation, with the inferred character state for the functional properties of the amniote and tetrapod ancestral receptors almost mirroring those of their extant counterparts (Marcovich et al., 2020).

On the basis of all the above, Marcovich et al. (2020) have proposed that in neurons, functional diversification could have arisen from stochastic changes in the expression patterns of receptor subunits, resulting in a given cell changing the subtype of receptor it expresses, while preserving individual subunit functionality. Consequently, the selection pressure for functionally distinct neuronal nAChRs could have more likely fallen on stochastic changes that affect the expression patterns of alternative subunits. Moreover, an additional substrate for functional divergence of neuronal nAChRs may derive from changes in the expression pattern and/ or function of chaperon proteins that influence the post-translational assembly and surface expression of neuronal subunits (Koperniak et al., 2013; Gu et al., 2016, 2019; Matta et al., 2017; Dawe et al., 2019; Kweon et al., 2020). This is overall in agreement with the low degree of coding sequence divergence observed for most brain expressed genes, associated with random changes in their non-coding regions leading to differential expression patterns across brain areas or species (Hoekstra and Coyne, 2007; Haygood et al., 2010). A comprehensive analysis of the promoter and enhancer regulatory regions of the genes coding for nAChR subunits, accessory and chaperon proteins and other components of cholinergic synapses, will contribute to improving our understanding of their evolution in the vertebrate nervous system.

\section{EVOLUTION OF MUSCLE nAChRs}

Muscle nAChRs are composed of two $\alpha 1$, one $\beta 1$, and one $\delta$ subunits, together with one $\gamma$-subunit in the fetal muscle $\mathrm{nAChR}$, or an $\varepsilon$-subunit in the adult muscle nAChR (Karlin, 2002). This switch in subunit composition results in changes in several functional properties (recently reviewed in Cetin et al., 2020). The complement of five muscle nAChR subunits is conserved in vertebrates, though some non-mammalian muscle orthologs are yet to be unequivocally mapped to their respective genomes. For example, the $\beta 1$ and $\varepsilon$ subunits have not been yet annotated on several of the current avian, reptilian, and/or amphibian genome assemblies. Of note, the $\beta 1$ subunit has been identified, using more intensive search tools, in the annotated genomes of painted and Chinese soft-shell turtles, python, and American alligator. The $\varepsilon$ subunit has been likewise reported in python, turtle, American alligator, and frog genomes (Pedersen et al., 2019; Marcovich et al., 2020). Both the $\beta 1$ and $\varepsilon$ subunits from Xenopus have been cloned from a cDNA library and functionally studied (Kullberg et al., 1994; Sullivan et al., 2004), and a partial cDNA clone for the $\beta 1$ subunit from chicken has also been reported (Moss et al., 1987). This indicates that as genome coverage, assembly, and annotation improve for avian/reptilian species, in particular for the underrepresented micro chromosomes (e.g., International Chicken Genome Sequencing Consortium, 2004; Liu et al., 2021), the $\beta 1$ and $\varepsilon$ subunits are likely to be definitively mapped. For example, a transcript (ENSGALG00000054377.1) annotated in the latest Gallus gallus genome assembly (GRCg6a) and localised to an unspecified scaffold, corresponds to a reported partial cDNA clone of the chicken $\beta 1$ subunit (Moss et al., 1987). Finally, a local duplication of the CHRNB1 gene has been described in spotted gar and teleosts (Pedersen et al., 2019).

Variability in the coding sequence of muscle $\mathrm{nAChR}$ subunits is somewhat higher than the general conservation observed for neuronal subunits. Overall, sequence identity is lower for all 
vertebrate muscle subunits, with the highest divergence observed for the $\gamma$ and $\varepsilon$ subunits (Marcovich et al., 2020). Additionally, phylogenetic analysis of vertebrate subunits shows varying rates of amino acid changes among tetrapod coding sequences for the $\varepsilon$ subunit (Pedersen et al., 2019).

The change in subunit composition from the fetal to the adult muscle $\mathrm{nAChR}$ conformation affects receptor expression, localisation, and functional properties (Tapia et al., 2012; Cetin et al., 2020). The switch from $\gamma$ to $\varepsilon$ subunit is accompanied by the clustering of receptors on well-defined end plates innervated by a single fibre (Cetin et al., 2020). Functionally, the fetal muscle nAChR shows lower conductance, but significantly longer opening times, accompanied by higher sensitivity to ACh and choline, slower recovery from desensitised states and lower relative calcium permeability than the adult counterpart (Fucile et al., 2006; Cetin et al., 2020). This functional shift is closely linked to the expression and morphological changes that characterise the maturation of the neuromuscular junction. For example, replacing the fetal $\gamma$ subunit with a chimeric $\gamma^{\varepsilon}$ subunit which bares functional $\varepsilon$-like properties, substantially alters the innervation pattern of muscle by motor nerve fibres, resulting in the formation of functional neuromuscular synapses outside the central end-plate band region in the diaphragm (Koenen et al., 2005).

In addition to the striking developmental differences between subtypes of muscle nAChRs driven by changes in subunit composition, interspecies differences in functional properties have also been observed. The human adult muscle receptor has significantly higher calcium permeability than the mouse counterpart, and this is driven by differences within the $\varepsilon$ subunit (Fucile et al., 2006). The physiological consequences of the increased calcium permeability are yet to be explored. However, this observation suggests that muscle receptors may sit somewhere in between neuronal and hair cell receptors in terms of the likely targets of functional selection pressure, with both changes in subunit composition and coding sequence contributing to functional changes.

\section{EVOLUTION OF HAIR CELL nAChRs}

Hair cell $\alpha 9 \alpha 10$ nAChRs are distinct from other nicotinic receptors in that a greater divergence in their coding sequence has translated into differential functional properties across clades (Lipovsek et al., 2012, 2014; Boffi et al., 2017; Marcovich et al., 2020; Moglie et al., 2021a). The only functional nAChR in inner ear hair cells is composed of $\alpha 9$ and $\alpha 10$ subunits. Extensive phylogenetic analysis of their coding sequences has revealed unique features about their evolutionary history (Franchini and Elgoyhen, 2006; Lipovsek et al., 2012, 2014; Marcovich et al., 2020). Most notably, while the sequences for each of the vertebrate $\mathrm{nAChR}$ subunits group within their own respective branches, denoting a high degree of coding sequence conservation, $\alpha 10$ subunits are unique in presenting a segregated grouping of orthologs, with non-mammalian $\alpha 10$ subunits as a sister group to all $\alpha 9$ subunits, and mammalian $\alpha 10$ subunits as an outgroup to the $\alpha 9 /$ non-mammalian $\alpha 10$ branch (Franchini and Elgoyhen, 2006; Lipovsek et al., 2012; Faltine-Gonzalez and
Layden, 2019; Marcovich et al., 2020). The segregated grouping of $\alpha 10$ orthologs is due to an overall low percentage of amino acid sequence identity amongst vertebrate $\alpha 10$ subunits, resulting from a high rate of acquisition of non-synonymous substitutions in the coding region of mammalian $\alpha 10$ subunits (Franchini and Elgoyhen, 2006; Lipovsek et al., 2012), followed by high sequence conservation within the mammalian lineage (Franchini and Elgoyhen, 2006; Lipovsek et al., 2012; Marcovich et al., 2020). A faster rate in amino acid changes for the CHRNA10 gene in humans, mouse, and opossum compared to other non-mammalian vertebrates has also been described (Pedersen et al., 2019). These non-synonymous changes observed in mammalian CHRNA10 could have resulted from Darwinian positive selection. Indeed, signatures of positive selection acting on CHRNA10 coding sequences have been observed utilising different molecular evolution analysis, including $\mathrm{Ka} / \mathrm{Ks}$ (non-synonymous substitutions per non-synonymous site/synonymous substitutions per synonymous site) and codon-based likelihood models (Franchini and Elgoyhen, 2006; Lipovsek et al., 2012). Moreover, the search for site-specific shifts in the amino acid biochemical state between clades ( $\mathrm{Gu}$ et al., 2013), indicates functionally significant amino acid changes when comparing $\alpha 10$ mammalian subunits vs. their sauropsid counterparts (Marcovich et al., 2020).

Several of the positively selected sites identified in the $\alpha 10$ subunit are located within the ligand-binding and gating regions of the extracellular domain (Franchini and Elgoyhen, 2006; Lipovsek et al., 2012). Moreover, the rat $\alpha 10$ subunit shows a relative excess of positively charged residues ( $R$ and $K$ ) in the $\mathrm{N}$-terminal extracellular domain compared to chicken $\alpha 10$, and chicken and rat $\alpha 9$ subunits (Boffi et al., 2017), which could potentially affect the interactions with the ligand through electrostatic repulsion. For example, residue 117 (numbering corresponds to Torpedo $\alpha 1$ subunit mature protein (Karlin, 2002) of Loop E in the complementary component of the binding site, is a positively charged arginine (R117, Figure 1B) in mammalian $\alpha 10$ subunits and a non-charged threonine or methionine in $\alpha 9$ and non-mammalian $\alpha 10$ subunits. Homology models of the extracellular domain with ACh docked in the binding site show that the positively charged R117 in $\alpha 10$ is located $\sim 8-9 \AA$ from the ACh amino group. It could therefore directly interact with the ligand and contribute to the differences in ligand binding and gating observed between rat and chicken $\alpha 9 \alpha 10 \mathrm{nAChRs} \mathrm{(Boffi}$ et al., 2017).

Overall, when comparing functional properties, stark differences are observed between mammalian and non-mammalian $\alpha 9 \alpha 10$ nAChRs, which may, in turn, relate to the accumulation of amino acid changes within mammalian $\alpha 10$ subunits. First, chicken, but not rat $\alpha 10$ subunits, assemble into functional homomeric receptors (Lipovsek et al., 2014; Moglie et al., 2021a). Second, while the chicken $\alpha 10$ subunit can contribute both principal and complementary components to the ligand binding site, the accumulation of non-synonymous substitutions in mammalian $\alpha 10$ subunits suggests a potentially defective contribution of rat (but not chicken) $\alpha 10$ subunits to complementary components of the binding site of $\alpha 9 \alpha 10$ nAChRs. Site-directed mutagenesis 
experiments, ligand binding assays, and molecular docking studies provide experimental support for this hypothesis (Boffi et al., 2017).

In addition, whereas the complementary face of the $\alpha 10$ subunit does not play an important role in the activation of the rat $\alpha 9 \alpha 10$ receptor by ACh (Boffi et al., 2017), it is strictly required for receptor activation by choline (Moglie et al., 2021a). Therefore, the evolutionary changes acquired in the mammalian $\alpha 10 \mathrm{nAChR}$ subunit resulted in the loss of choline acting as a full agonist in rat $\alpha 9 \alpha 10 \mathrm{nAChRs}$ (Moglie et al., 2021a). Since choline is present at the synaptic cleft, due to ACh hydrolysis by acetylcholinesterase, this difference in the efficacy of choline on $\alpha 9 \alpha 10$ nAChRs might result in different kinetics of efferent synapses across species.

Molecular evolution analysis of the $\alpha 9$ subunits indicated no statistically significant evidence of positive selection on the coding sequences (Franchini and Elgoyhen, 2006; Lipovsek et al., 2014). However, mammalian $\alpha 9$ subunits show a higher prevalence of non-synonymous substitutions (Lipovsek et al., 2014) and functionally significant amino acid changes along the protein when comparing the $\alpha 9$ mammalian vs. sauropsid (birds and reptiles) clades (Marcovich et al., 2020). Moreover, ancestral sequence reconstruction of all the nodes of the $\alpha 9$ tetrapod phylogeny indicates a greater degree of divergence from the common amniote ancestor for the mammalian lineage, contrasting against the greater sequence conservation on the sauropsid lineage (Lipovsek et al., 2014). A zoom into the alignment of the extant tetrapod sequences and those predicted for the major clade nodes showed that when comparing mammalian vs. sauropsid $\alpha 9$ amino acid sequences, both branching from the ancestral amniote, 42 sites had non-synonymous branch-specific substitutions and that the majority of them (36 of the 42 changes) occurred in the mammalian lineage (Lipovsek et al., 2014). Altogether, the DIVERGE analysis coupled to the ancestral sequence reconstruction, suggest that clade-specific functionally significant amino acid changes also occurred during the evolution of mammalian $\alpha 9 \mathrm{nAChR}$ subunits, albeit with a lower prevalence when compared to $\alpha 10$ subunits. Using molecular dynamics simulations and an evolutionary-based mutagenesis strategy, Lipovsek et al. (2014) identified three specific amino acid substitutions in the $\alpha 9$ subunit that rendered a high calcium permeable mammalian (but not chicken) $\alpha 9 \alpha 10 \mathrm{nAChR}$, stemming from a low calcium permeable amniote ancestor. These sites are located at the extracellular vestibule (D110 and S127) and at the exit of the channel pore (4'A; Lipovsek et al., 2014), and not at the pore-forming transmembrane region 2 of the protein as previously proposed (Galzi et al., 1992; Bertrand et al., 1993; Tapia et al., 2007). Thus, though lower in numbers, mammalian-specific non-synonymous substitutions on the $\alpha 9$ subunit led to important functional changes in the properties of the $\alpha 9 \alpha 10 \mathrm{nAChR}$.

The phylogenetic analysis of the entire nAChR family shows that the average percentage of sequence identity between all pairs of sequences is lowest for non-vertebrate $\alpha 10$ subunits (64.25\%; Figure 3 and Marcovich et al., 2020). This suggests that the functional properties of $\alpha 9 \alpha 10 \mathrm{nAChRs}$ may not only differ when comparing mammalian vs. non-mammalian vertebrates but also along other branches of the tetrapod tree. In order to test this hypothesis, Marcovich et al. (2020) performed a comprehensive analysis of functional and biophysical properties of $\alpha 9 \alpha 10$ receptors, comparing three representative tetrapod species (rat, chicken, and frog), and observed striking differences across them, denoting major functional divergence. This contrasts the high degree of functional conservation observed for tetrapod neuronal ( $\alpha 4 \beta 2$ and $\alpha 7$ ) nAChRs, as discussed above.

Taken together, the inter-clade sequence divergence and the positive selection of non-synonymous substitutions in mammalian $\alpha 9$ and/or $\alpha 10$ subunits, indicate that the evolution of the hair cell $\mathrm{nAChR}$ has been dominated by functionally significant changes on the coding sequences. This evolutionary trajectory of the hair cell nAChR mirrors what has been recently described for an increasing number of inner ear expressed genes. Noticeably, as much as $13 \%$ of 1,300 inner ears expressed genes show signatures of positive selection in the mammalian lineage, spotting adaptive molecular evolution as a major player in the emergence of morphological and functional innovations in the mammalian inner ear (Pisciottano et al., 2019).

\section{EVOLUTION OF THE OCTAVOLATERAL EFFERENT SYSTEM}

The main functional role described to date for the $\alpha 9 \alpha 10 \mathrm{nAChR}$ is to mediate transmission at efferent fibres-hair cells synapses. It is therefore important to analyse the distinct evolutionary trajectory of this receptor within the context of the octavolateral system. This comprises the lateral line, vestibular and auditory sensory modalities that utilise highly specialised mechanosensory hair cells, equipped with stereocilia at their apical ends, for the detection of vibrations originating from water waves, sounds, and head and body movements. The origins of epithelial mechanosensory hair cells can be traced to the earliest vertebrates (Manley and Fuchs, 2011; Sienknecht et al., 2014; Arendt et al., 2016; Fritzsch and Elliott, 2017). Homologous mechanosensory cells have also been described in tunicates, the invertebrate chordates that are a sister group of vertebrates (Manni et al., 2006; Rigon et al., 2018).

Cholinergic responses, driven by the $\alpha 9 \alpha 10$ receptor, have been most extensively studied in rodents (Katz et al., 2004, 2011; Gomez-Casati et al., 2005; Lipovsek et al., 2012; Katz and Elgoyhen, 2014; Moglie et al., 2018, 2021b; Kearney et al., 2019) and avian (Fuchs and Murrow, 1992a,b; Lipovsek et al., 2014; Moglie et al., 2021a) auditory hair cells. Additionally, functional hair cell nAChRs have also been reported in reptiles and fish (Art and Fettiplace, 1984; Art et al., 1985; Holt et al., 2006; Parks et al., 2017; Carpaneto Freixas et al., 2021). To date, the presence of hair cell-like nAChRs is yet to be described in non-vertebrate chordates. However, the identification of such receptors in, for example, mechanosensory cells of the ascidian coronal organ, would lend additional support to the hypothesis of a common origin for chordate mechanosensory cells.

Hair cells receive afferent innervation, through which they relay mechanosensory information to the brain, and efferent innervation, that modulates hair cell activity. Efferent 
innervation is a prominent feature of mechanosensory organs, observed contacting mechanosensory cells in vertebrates, in the tunicate coronal organ (Manni et al., 2006; Rigon et al., 2018), the statocyst of octopus (Colmers, 1982) and the Johnston's organ of mosquitoes (Andrés et al., 2016). However, efferent neurons are unlikely to represent homologous cell types across Bilateria. In vertebrates, efferent innervation is prominent in the inner ear, targeting both vestibular and auditory sensory epithelia, and in lateral line neuromasts (although it may have been secondarily lost in cyclostomes; Rigon et al., 2018). It is therefore as old as, and has co-evolved with, hair cells (Manley and Köppl, 1998). The cell bodies of efferent neurons are located in the hindbrain. A single efferent nucleus is present in diapsids, although in birds and some reptiles there is a partial segregation of auditory and vestibular efferents, with the latter located more dorsally (Holt et al., 2011; Cullen and Wei, 2021). In mammals, sensory modalities are completely segregated, with vestibular efferent neurons located in the dorsal hindbrain, and auditory efferent neurons localised ventrally, within the olivary complex (Holt et al., 2011; Di Bonito and Studer, 2017). In line with this, efferent innervation has been described to produce a global control of a range of end organs, including auditory, vestibular and, if present, lateral line (Manley and Köppl, 1998; Holt et al., 2011; Köppl, 2011b; Sienknecht et al., 2014). Functional studies in fish and amphibians suggest that efferent activity works as a shut-off system to prevent desensitization of peripheral sensory systems and aids detection of external vs. self-generated stimuli (Lunsford et al., 2019; Pichler and Lagnado, 2020). In amniotes, the efferent system likely adapted to provide anti-masking effects to improve signal detection (Guinan, 2010). Based on the spatial and developmental associations of the efferent neurons with facial motor neurons, in addition to their cholinergic nature, it has been proposed that inner ear efferents are evolutionarily related to facial motor neurons (Fritzsch and Elliott, 2017; Di Bonito and Studer, 2017; Frank and Goodrich, 2018).

The segregation of vestibular and auditory efferent neurons is likely part of widespread changes in the octavolateral system that followed the transition to land and ultimately led to specialisations for the detection of airborne sounds (Manley, 2000, 2017; Fritzsch and Straka, 2014; Grothe and Pecka, 2014; Clack, 2015; Carr and Christensen-Dalsgaard, 2016). The independent emergence of at least five variants of a tympanic middle ear, more than 100 million years after the separation of the tetrapod lineages (Manley, 2000; Anthwal et al., 2013; Clack, 2015; Carr and Christensen-Dalsgaard, 2016; Tucker, 2017), was accompanied by parallel evolutionary processes in the auditory systems of amniotes, that also involved the independent elongation of the sensory epithelia, extension of the hearing range to higher frequencies, and elaboration of passive and active sound amplification mechanisms, leading to fine-tuning of sound detection (Hudspeth, 1997; Manley, 2000, 2017; Dallos, 2008). In addition, mammals and sauropsids underwent independent specialization of hair cell types, segregating, partially in birds and completely in mammals, their phonoreception [tall hair cells in birds and inner hair cells (IHCs) in mammals], and sound amplification functions [short hair cells in birds and outer hair cells (OHCs) in mammals; Köppl, 2011a]. Moreover, mammals developed a novel mechanism of active sound amplification and basilar membrane fine-tuning based on $\mathrm{OHC}$ length changes termed somatic electromotility (Brownell et al., 1985). In adult mammals, medial olivocochlear efferent fibres synapse directly onto $\mathrm{OHCs}$ and modulate somatic electromotility, while lateral olivocochlear fibres contact the afferent synaptic boutons that, in turn, contact IHCs. During a short developmental time window, medial olivocochlear fibres directly contact IHCs (Glowatzki and Fuchs, 2000; Katz et al., 2004). During this period, efferent activity modulates the spontaneous activity of IHCs, affecting the maturation of IHCs themselves (Johnson et al., 2013) and of tonotopic maps along the ascending auditory pathway (Clause et al., 2014; Di Guilmi et al., 2019).

Overall, the degree of specialisation reached by amniote, and in particular mammalian, hearing highlights the strong evolutionary pressures that shaped the different components of the auditory system. The expansion of the hearing range to higher frequencies and the emergence of an active amplification mechanism for its fine-tuning presented new challenges for their modulation. In this context, the evolutionary changes in the coding sequence of the $\alpha 9 \alpha 10$ nAChRs likely accompanied the specialization of the efferent system across the different vertebrate clades. In particular, a number of functional properties of mammalian $\alpha 9 \alpha 10$ nAChRs suggest a role in highly reliable, high-frequency synaptic transmission for the modulation of electromotile OHCs. Thus, exclusively in mammals, efferent activation of $\alpha 9 \alpha 10 \mathrm{nAChRs}$ presents a different set of challenges for efferent modulation, since it inhibits OHC somatic electromotility, which is driven by the motor protein prestin (Zheng et al., 2000). Noticeably, prestin and $\beta \mathrm{V}$ giant spectrin (a major component of the OHCs' cortical cytoskeleton) also show signals of positive selection in mammals, accompanying the acquisition of somatic electromotility (Franchini and Elgoyhen, 2006; Elgoyhen and Franchini, 2011; Cortese et al., 2017), and representing a prominent example of evolutionary processes focussed on the coding sequence of inner ear-specific genes (Pisciottano et al., 2019).

Although across species calcium influx through $\alpha 9 \alpha 10$ nAChRs activates SK potassium channels (Fuchs and Murrow, 1992a; Glowatzki and Fuchs, 2000), as described above, mammalian $\alpha 9 \alpha 10$ nAChRs have a higher calcium permeability than their avian counterparts (Lipovsek et al., 2012, 2014). This differential calcium permeability might accompany alternative demands in efferent modulation of hair cell activity across species. First, a strong influx of calcium may be required for the activation of large conductance, voltage, and low-calciumsensitive BK potassium channels that mediate hyperpolarization of OHCs in the basal higher frequency regions of the cochlea (Wersinger et al., 2010; Rohmann et al., 2015). Second, in addition to activating SK (or BK) potassium channels, calcium entry through $\alpha 9 \alpha 10 \mathrm{nAChRs}$ is also involved in triggering calcium-induced calcium-release from postsynaptic cisterns that are present at efferent synapsis of birds and mammals (Fuchs et al., 2014; Im et al., 2014; Fuchs and Lauer, 2019). However, the relative contributions of calcium influx and store 
release differs between avian and mammalian hair cells, with chicken short hair cells likely relying more heavily on the latter (Lipovsek et al., 2012). Third, it can be hypothesized that in mammals the time course of potassium channel activation (and therefore $\mathrm{OHC}$ inhibition) would rely mainly on calcium entry through $\alpha 9 \alpha 10$ receptors, and therefore more precisely follow efferent fibre activity allowing for a graded modulation of the cochlear amplifier, as opposed to the all-or-none feature typical of calcium release from intracellular stores. Finally, while in adult mammalian hair cells efferent fibres directly contact $\mathrm{OHCs}$ and not the IHCs that release glutamate onto afferent auditory fibres, efferent innervation in birds and amphibians coexists with glutamate releasing afferent innervation in the same sensory hair cells (Simmons et al., 1996), with the exception of the extremely tall and short hair cells in some birds. Therefore, in these non-mammalian clades, limiting the efferent-mediated calcium influx may be fundamental to avoid a possible efferent-to-afferent calcium spillover (Moglie et al., 2018, 2021b), which could lead to glutamate release independent of sound driven mechanosensory activation. The low calcium permeability of chicken $\alpha 9 \alpha 10$ nAChRs (Lipovsek et al., 2012, 2014) and the very high desensitization kinetics of amphibian $\alpha 9 \alpha 10$ receptors (Marcovich et al., 2020) may therefore be crucial to limit a potential hair cell calcium load triggered by efferent activity.

Another functional consequence of the accumulated changes in the amino acid sequences of the $\alpha 9 \alpha 10$ receptor is the differential efficacy of choline for receptor activation. While choline elicits maximal responses in recombinant and native chicken $\alpha 9 \alpha 10$ receptors, it behaves as a weak partial agonist (and competitive antagonist) of rodent $\alpha 9 \alpha 10$ receptors (Moglie et al., 2021a). Since choline is the metabolite produced by ACh degradation at the synaptic cleft, its interaction with the $\alpha 9 \alpha 10 \mathrm{nAChR}$ might influence the kinetics of synaptic transmission. Thus, in chicken, choline will continue to activate the receptor until it is removed from the synaptic cleft, resulting in longer post-synaptic responses subjected to large variations and poor temporal tuning. In contrast, in mammals, the termination of $\alpha 9 \alpha 10$ responses would be determined by the fast kinetics of acetylcholinesterase activity (Hall, 1973) and the degradation of $\mathrm{ACh}$ to choline would limit the time-course and improve the reliability of synaptic responses. This may be fundamental for the modulation of the prestindriven amplifier of mammalian OHCs since it might allow the characteristic post-synaptic summation of efferent responses that faithfully reproduce the high frequency activity of efferent medial olivocochlear fibres (Ballestero et al., 2011).

\section{DISCUSSION}

The hair cell $\alpha 9 \alpha 10$ receptor is an unusual nAChR. It differs from its muscle and neuronal cousins across many features. At the coding sequence level, it shows the greatest degree of divergence of all vertebrate nicotinic receptors, with clear signs of positive selection and functional shifts in amino acid residues. At the expression level, it shows restricted expression patterns, with co-expression of both $\alpha 9$ and $\alpha 10$ limited almost exclusively to inner ear or lateral line hair cells, the only cell type where functional $\alpha 9 \alpha 10$ receptors have been identified to date. At the subunit assembly level, $\alpha 9$ and $\alpha 10$ show remarkable isolation, only forming functional pentamers with each other, and are likely to require completely different sets of chaperone and accessory proteins. Finally, it is at the functional level where $\alpha 9 \alpha 10$ receptors most clearly show their colours, in stark contrast to other nAChRs, with numerous differences between $\alpha 9 \alpha 10$ receptors across vertebrate clades. All these have delineated (or has been influenced by) a unique evolutionary trajectory for the hair cell receptor along the vertebrate phylogeny, that contrasts that of other members of the family. Moreover, amounting evidence supports a close link between the evolutionary processes affecting the hair cell receptor and those that have shaped the octavolateral system.

Ever since the cloning and functional characterisation of the first $\alpha 9$ subunit (Elgoyhen et al., 1994), the peculiarities of the hair cell receptor have made it an interesting, yet challenging area of research. Overall, the study of $\alpha 9 \alpha 10$ receptors has contributed to deepening our knowledge of nicotinic acetylcholine receptors. Comparative studies across the gene family have led to the formulation of new hypotheses about the evolutionary processes that shaped its members (Marcovich et al., 2020). A corollary of the divergent evolutionary history of the $\alpha 9 \alpha 10 \mathrm{nAChR}$ has been the suggestion that the hair cell receptor is the most ancestral member of the group of paralogue genes. Although there is a clear consensus that the $\alpha 9$ and $\alpha 10$ subunits were indeed present in the last common ancestor of all vertebrates, alongside most other nicotinic subunits, no evidence to date supports the notion that $\alpha 9$-like subunits represent neither the ancestral state of nicotinic subunits nor that they were the first ones to branch-off from the original stem branch of nicotinic subunits. As discussed above, the presence of an $\alpha 9$-like subunit in the last common ancestor to Bilateria is yet to be unequivocally identified. The hair cell receptor is therefore in all likelihood not older than any other vertebrate nicotinic receptor, be them of the muscle or neuronal subtypes. Nonetheless, $\alpha 9 \alpha 10$ receptors are the most divergent $\mathrm{nAChR}$ in vertebrates. Future functional and molecular evolution studies will continue to shed light on the many peculiar features of $\alpha 9 \alpha 10$ receptors and continue to contribute insight into the evolutionary history of nAChRs and that of the efferent modulation of mechanosensation.

\section{AUTHOR CONTRIBUTIONS}

All authors wrote the review and approved the submitted version.

\section{FUNDING}

This work was supported by Agencia Nacional de Promoción Científica y Técnica and Scientific Grand Prize from the Fondation Pour L'Audition, NIH grant R01 DC001508 (Paul Fuchs PI and AE co-PI) to AE and a Sir Henry Dale Fellowship jointly funded by the Wellcome Trust and the Royal Society (Grant Number 220622/Z/20/Z) to ML. 


\section{REFERENCES}

Althoff, T., Hibbs, R. E., Banerjee, S., and Gouaux, E. (2014). X-ray structures of $\mathrm{GluCl}$ in apo states reveal a gating mechanism of Cys-loop receptors. Nature 512, 333-337. doi: 10.1038/nature13669

Amundarain, M. J., Ribeiro, R. P., Costabel, M. D., and Giorgetti, A. (2019). GABA(A) receptor family: overview on structural characterization. Future Med. Chem. doi: 10.4155/fmc-2018-0336. [Epub ahead of print].

Andrés, M., Seifert, M., Spalthoff, C., Warren, B., Weiss, L., Giraldo, D., et al. (2016). Auditory efferent system modulates mosquito hearing. Curr. Biol. 26, 2028-2036. doi: 10.1016/j.cub.2016.05.077

Anthwal, N., Joshi, L., and Tucker, A. S. (2013). Evolution of the mammalian middle ear and jaw: adaptations and novel structures. J. Anat. 222, 147-160. doi: 10.1111/j.1469-7580.2012.01526.x

Arendt, D., Musser, J. M., Baker, C. V. H., Bergman, A., Cepko, C., Erwin, D. H., et al. (2016). The origin and evolution of cell types. Nat. Rev. Genet. 17, 744-757. doi: 10.1038/nrg.2016.127

Arredondo, J., Nguyen, V. T., Chernyavsky, A. I., Bercovich, D., Orr-Urtreger, A., Kummer, W., et al. (2002). Central role of $\alpha 7$ nicotinic receptor in differentiation of the stratified squamous epithelium. J. Cell Biol. 159, 325-336. doi: $10.1083 /$ jcb. 200206096

Art, J. J., Crawford, A. C., Fettiplace, R., and Fuchs, P. A. (1985). Efferent modulation of hair cell tuning in the cochlea of the turtle. J. Physiol. 360, 397-421. doi: 10.1113/jphysiol.1985.sp015624

Art, J. J., and Fettiplace, R. (1984). Efferent desensitization of auditory nerve fibre responses in the cochlea of the turtle Pseudemys scripta elegans. J. Physiol. 356, 507-523. doi: 10.1113/jphysiol.1984.sp015480

Atlas, A. B. (2013). Accelerating Progress Toward Understanding the Brain. Available online at: https://portal.brain-map.org/.

Ballestero, J., Zorrilla de San Martin, J., Goutman, J., Elgoyhen, A. B., Fuchs, P. A., and Katz, E. (2011). Short-term synaptic plasticity regulates the level of olivocochlear inhibition to auditory hair cells. J. Neurosci. 31, 14763-14774. doi: 10.1523/JNEUROSCI.6788-10.2011

Barnes, N. M., Hales, T. G., Lummis, S. C., and Peters, J. A. (2009). The 5-HT3 receptor-the relationship between structure and function. Neuropharmacology 56, 273-284. doi: 10.1016/j.neuropharm.2008.08.003

Benallegue, N., Mazzaferro, S., Alcaino, C., and Bermudez, I. (2013). The additional ACh binding site at the $\alpha 4(+) / \alpha 4(-)$ interface of the $(\alpha 4 \beta 2) 2 \alpha 4$ nicotinic ACh receptor contributes to desensitization. $B r$. J. Pharmacol. 170, 304-316. doi: 10.1111/bph.12268

Bertrand, D., Galzi, J., Devillers-Thiery, A., Bertrand, S., and Changeux, J. (1993). Mutations at two distinct sites within the channel domain M2 alter calcium permeability of neuronal $\alpha 7$ nicotinic receptor. Proc. Natl. Acad. Sci. U S A 90, 6971-6975. doi: 10.1073/pnas.90.15.6971

Betz, H., and Laube, B. (2006). Glycine receptors: recent insights into their structural organization and functional diversity. J. Neurochem. 97, 1600-1610. doi: 10.1111/j.1471-4159.2006.03908.x

Blanchet, C., Eróstegui, C., Sugasawa, M., and Dulon, D. (1996). Acetylcholineinduced potassium current of guinea pig outer hair cells: its dependence on a calcium influx through nicotinic-like receptors. J. Neurosci. 16, 2574-2584. doi: 10.1523/JNEUROSCI.16-08-02574.1996

Blount, P., and Merlie, J. P. (1990). Mutational analysis of muscle nicotinic acetylcholine receptor subunit assembly. J. Cell Biol. 111, 2613-2622. doi: $10.1083 /$ jcb.111.6.2613

Bocquet, N., Nury, H., Baaden, M., Le Poupon, C., Changeux, J. P., Delarue, M., et al. (2009). X-ray structure of a pentameric ligand-gated ion channel in an apparently open conformation. Nature 457, 111-114. doi: 10.1038/nature07462

Bocquet, N., Prado de Carvalho, L., Cartaud, J., Neyton, J., Le Poupon, C., Taly, A., et al. (2007). A prokaryotic proton-gated ion channel from the nicotinic acetylcholine receptor family. Nature 445, 116-119. doi: 10.1038/nature05371

Boffi, J. C., Marcovich, I., Gill-Thind, J. K., Corradi, J., Collins, T., Lipovsek, M. M., et al. (2017). Differential contribution of subunit interfaces to $\alpha 9 \alpha 10$ nicotinic acetylcholine receptor function. Mol. Pharmacol. 91, 250-262. doi: $10.1124 / \mathrm{mol} .116 .107482$

Brejc, K., van Dijk, W. J., Klaassen, R. V., Schuurmans, M., van Der Oost, J., Smit, A. B., et al. (2001). Crystal structure of an ACh-binding protein reveals the ligand-binding domain of nicotinic receptors. Nature 411, 269-276. doi: $10.1038 / 35077011$
Brown, R. W., Collins, A. C., Lindstrom, J. M., and Whiteaker, P. (2007). Nicotinic $\alpha 5$ subunit deletion locally reduces high-affinity agonist activation without altering nicotinic receptor numbers. J. Neurochem. 103, 204-215. doi: 10.1111/j. 1471-4159.2007.04700.x

Brownell, W. E., Bader, C. R., Bertrand, D., and de Ribaupierre, Y. (1985). Evoked mechanical responses of isolated cochlear hair cells. Science 227, 194-196. doi: 10.1126/science.3966153

Brüss, M., Barann, M., Hayer-Zillgen, M., Eucker, T., Göthert, M., and Bönisch, H. (2000). Modified 5-HT3A receptor function by co-expression of alternatively spliced human 5-HT3A receptor isoforms. Naunyn Schmiedebergs Arch. Pharmacol. 362, 392-401. doi: 10.1007/s002100000342

Burns, J. C., Kelly, M. C., Hoa, M., Morell, R. J., and Kelley, M. W. (2015). Singlecell RNA-Seq resolves cellular complexity in sensory organs from the neonatal inner ear. Nat. Commun. 6:8557. doi: 10.1038/ncomms9557

Cai, T., Jen, H. I., Kang, H., Klisch, T. J., Zoghbi, H. Y., and Groves, A. K. (2015). Characterization of the transcriptome of nascent hair cells and identification of direct targets of the Atoh1 transcription factor. J. Neurosci. 35, 5870-5883. doi: 10.1523/JNEUROSCI.5083-14.2015

Carpaneto Freixas, A. E., Moglie, M. J., Castagnola, T., Salatino, L., Domene, S., Marcovich, I., et al. (2021). Unraveling the molecular players at the cholinergic efferent synapse of the zebrafish lateral line. J. Neurosci. 41, 47-60. doi: 10.1523/JNEUROSCI.1772-20.2020

Carr, C. E., and Christensen-Dalsgaard, J. (2016). Evolutionary trends in directional hearing. Curr. Opin. Neurobiol. 40, 111-117. doi: 10.1016/j.conb. 2016.07.001

Cetin, H., Beeson, D., Vincent, A., and Webster, R. (2020). The structure, function and physiology of the fetal and adult acetylcholine receptor in muscle. Front. Mol. Neurosci. 13:581097. doi: 10.3389/fnmol.2020.581097

Changeux, J. P., Giraudat, J., and Dennis, M. (1987). The nicotinic acetylcholine receptor: molecular architecture of a ligand-regulated ion channel. Trends Pharmacol. Sci. 8, 459-465. doi: 10.1016/0165-6147(87)90039-3

Clack, J. A. (2015). Evolutionary biology: the origin of terrestrial hearing. Nature 519, 168-169. doi: 10.1038/519168a

Clause, A., Kim, G., Sonntag, M., Weisz, C. J., Vetter, D. E., Rubsamen, R., et al. (2014). The precise temporal pattern of prehearing spontaneous activity is necessary for tonotopic map refinement. Neuron 82, 822-835. doi: 10.1016/j. neuron.2014.04.001

Colmers, W. F. (1982). The central afferent and efferent organization of the gravity receptor system of the statocyst of Octopus vulgaris. Neuroscience 7, 461-476. doi: 10.1016/0306-4522(82)90280-9

Cooper, E., Couturier, S., and Ballivet, M. (1991). Pentameric structure and subunit stoichiometry of a neuronal nicotinic acetylcholine receptor. Nature 350, 235-238. doi: 10.1038/350235a0

Corringer, P. J., Poitevin, F., Prevost, M. S., Sauguet, L., Delarue, M., and Changeux, J. P. (2012). Structure and pharmacology of pentameric receptor channels: from bacteria to brain. Structure 20, 941-956. doi: 10.1016/j.str.2012. 05.003

Cortese, M., Papal, S., Pisciottano, F., Elgoyhen, A. B., Hardelin, J. P., Petit, C., et al. (2017). Spectrin $\beta V$ adaptive mutations and changes in subcellular location correlate with emergence of hair cell electromotility in mammalians. Proc. Natl. Acad. Sci. U S A 114, 2054-2059. doi: 10.1073/pnas.1618778114

Covernton, P. J., Kojima, H., Sivilotti, L. G., Gibb, A. J., and Colquhoun, D. (1994). Comparison of neuronal nicotinic receptors in rat sympathetic neurones with subunit pairs expressed in Xenopus oocytes. J. Physiol. 481, 27-34. doi: 10.1113/jphysiol.1994.sp020416

Cullen, K. E., and Wei, R. H. (2021). Differences in the structure and function of the vestibular efferent system among vertebrates. Front. Neurosci. 15:684800. doi: 10.3389/fnins.2021.684800

Cutting, G. R., Lu, L., O’Hara, B. F., Kasch, L. M., Montrose-Rafizadeh, C., Donovan, D. M., et al. (1991). Cloning of the $\gamma$-aminobutyric acid (GABA) rho 1 cDNA: a GABA receptor subunit highly expressed in the retina. Proc. Natl. Acad. Sci. U S A 88, 2673-2677. doi: 10.1073/pnas.88.7.2673

Dallos, P. (2008). Cochlear amplification, outer hair cells and prestin. Curr. Opin. Neurobiol. 18, 370-376. doi: 10.1016/j.conb.2008.08.016

Dani, J. A., and Bertrand, D. (2007). Nicotinic acetylcholine receptors and nicotinic cholinergic mechanisms of the central nervous system. Annu. Rev. Pharmacol. Toxicol. 47, 699-729. doi: 10.1146/annurev.pharmtox.47.120505. 105214 
Davies, P. A., Wang, W., Hales, T. G., and Kirkness, E. F. (2003). A novel class of ligand-gated ion channel is activated by $\mathrm{Zn} 2+$. J. Biol. Chem. 278, 712-717. doi: 10.1074/jbc.M208814200

Dawe, G. B., Yu, H., Gu, S., Blackler, A. N., Matta, J. A., Siuda, E. R., et al. (2019). $\alpha 7$ nicotinic acetylcholine receptor upregulation by anti-apoptotic Bcl-2 proteins. Nat. Commun. 10:2746. doi: 10.1038/s41467-019-10723-x

Dellisanti, C. D., Yao, Y., Stroud, J. C., Wang, Z. Z., and Chen, L. (2007). Crystal structure of the extracellular domain of $\mathrm{nAChR} \alpha 1$ bound to $\alpha$-bungarotoxin at 1.94 A resolution. Nat. Neurosci. 10, 953-962. doi: 10.1038/nn1942

Dent, J. A. (2006). Evidence for a diverse Cys-loop ligand-gated ion channel superfamily in early bilateria. J. Mol. Evol. 62, 523-535. doi: 10.1007/s00239005-0018-2

Dent, J. A. (2010). The evolution of pentameric ligand-gated ion channels. $A d v$. Exp. Med. Biol. 683, 11-23. doi: 10.1007/978-1-4419-6445-8_2

Di Bonito, M., and Studer, M. (2017). Cellular and molecular underpinnings of neuronal assembly in the central auditory system during mouse development. Front. Neural Circuits 11:18. doi: 10.3389/fncir.2017.00018

Di Guilmi, M. N., Boero, L. E., Castagna, V. C., Rodríguez-Contreras, A., Wedemeyer, C., Gómez-Casati, M. E., et al. (2019). Strengthening of the efferent olivocochlear system leads to synaptic dysfunction and tonotopy disruption of a central auditory nucleus. J. Neurosci. 39, 7037-7048. doi: 10.1523/JNEUROSCI.2536-18.2019

Du, J., Lü, W., Wu, S., Cheng, Y., and Gouaux, E. (2015). Glycine receptor mechanism elucidated by electron cryo-microscopy. Nature 526, 224-229. doi: 10.1038/nature14853

Elgoyhen, A. B., and Franchini, L. F. (2011). Prestin and the cholinergic receptor of hair cells: positively-selected proteins in mammals. Hear. Res. 273, 100-108. doi: 10.1016/j.heares.2009.12.028

Elgoyhen, A. B., Johnson, D. S., Boulter, J., Vetter, D. E., and Heinemann, S. (1994). $\alpha$ 9: an acetylcholine receptor with novel pharmacological properties expressed in rat cochlear hair cells. Cell 79, 705-715. doi: 10.1016/0092-8674(94)90555-x

Elgoyhen, A. B., and Katz, E. (2012). The efferent medial olivocochlear-hair cell synapse. J. Physiol. Paris 106, 47-56. doi: 10.1016/j.jphysparis.2011.06.001

Elgoyhen, A. B., Vetter, D. E., Katz, E., Rothlin, C. V., Heinemann, S. F., and Boulter, J. (2001). $\alpha 10$ : a determinant of nicotinic cholinergic receptor function in mammalian vestibular and cochlear mechanosensory hair cells. Proc. Natl. Acad. Sci. U S A 98, 3501-3506. doi: 10.1073/pnas.051622798

Enz, R., and Cutting, G. R. (1998). Molecular composition of GABAC receptors. Vis. Res. 38, 1431-1441. doi: 10.1016/s0042-6989(97)00277-0

Faltine-Gonzalez, D. Z., and Layden, M. J. (2019). Characterization of nAChRs in Nematostella vectensis supports neuronal and non-neuronal roles in the cnidarian-bilaterian common ancestor. Evodevo 10:27. doi: 10.1186/s13227019-0136-3

Franchini, L. F., and Elgoyhen, A. B. (2006). Adaptive evolution in mammalian proteins involved in cochlear outer hair cell electromotility. Mol. Phylogenet. Evol. 41, 622-635. doi: 10.1016/j.ympev.2006.05.042

Frank, M. M., and Goodrich, L. V. (2018). Talking back: development of the olivocochlear efferent system. Wiley Interdiscip. Rev. Dev. Biol. 7:e324. doi: 10.1002/wdev.324

Fritzsch, B., and Elliott, K. L. (2017). Evolution and development of the inner ear efferent system: transforming a motor neuron population to connect to the most unusual motor protein via ancient nicotinic receptors. Front. Cell. Neurosci. 11:114. doi: 10.3389/fncel.2017.00114

Fritzsch, B., and Straka, H. (2014). Evolution of vertebrate mechanosensory hair cells and inner ears: toward identifying stimuli that select mutation driven altered morphologies. J. Comp. Physiol. A Neuroethol. Sens. Neural Behav. Physiol. 200, 5-18. doi: 10.1007/s00359-013-0865-Z

Fuchs, P. A., and Lauer, A. M. (2019). Efferent inhibition of the cochlea. Cold Spring Harb. Perspect. Med. 9:a033530. doi: 10.1101/cshperspect.a033530

Fuchs, P. A., Lehar, M., and Hiel, H. (2014). Ultrastructure of cisternal synapses on outer hair cells of the mouse cochlea. J. Comp. Neurol. 522, 717-729. doi: $10.1002 / \mathrm{cne} .23478$

Fuchs, P. A., and Murrow, B. W. (1992a). Cholinergic inhibition of short (outer) hair cells of the chick's cochlea. J. Neurosci. 12, 800-809. doi: 10.1523/JNEUROSCI.12-03-00800.1992

Fuchs, P. A., and Murrow, B. W. (1992b). A novel cholinergic receptor mediates inhibition of chick cochlear hair cells. Proc. Biol. Sci. 248, 35-40. doi: 10.1098/rspb.1992.0039
Fucile, S., Sucapane, A., and Eusebi, F. (2006). Ca2+ permeability through rat cloned $\alpha 9$-containing nicotinic acetylcholine receptors. Cell Calcium 39, 349-355. doi: 10.1016/j.ceca.2005.12.002

Fujii, T., Mashimo, M., Moriwaki, Y., Misawa, H., Ono, S., Horiguchi, K., et al. (2017). Expression and function of the cholinergic system in immune cells. Front. Immunol. 8:1085. doi: 10.3389/fimmu.2017.01085

Galzi, J. L., Devillers-Thiery, A., Hussy, N., Bertrand, S., Changeux, J. P., and Bertrand, D. (1992). Mutations in the channel domain of a neuronal nicotinic receptor convert ion selectivity from cationic to anionic. Nature 359, 500-505. doi: $10.1038 / 359500 \mathrm{a} 0$

Glowatzki, E., and Fuchs, P. A. (2000). Cholinergic synaptic inhibition of inner hair cells in the neonatal mammalian cochlea. Science 288, 2366-2368. doi: 10.1126/science.288.5475.2366

Gomez-Casati, M. E., Fuchs, P. A., Elgoyhen, A. B., and Katz, E. (2005). Biophysical and pharmacological characterization of nicotinic cholinergic receptors in rat cochlear inner hair cells. J. Physiol. 566, 103-118. doi: 10.1113/jphysiol.2005. 087155

Gotti, C., Clementi, F., Fornari, A., Gaimarri, A., Guiducci, S., Manfredi, I., et al. (2009). Structural and functional diversity of native brain neuronal nicotinic receptors. Biochem. Pharmacol. 78, 703-711. doi: 10.1016/j.bcp.2009. 05.024

Grothe, B., and Pecka, M. (2014). The natural history of sound localization in mammals-a story of neuronal inhibition. Front. Neural Circuits 8:116. doi: 10.3389/fncir.2014.00116

Gu, S., Matta, J. A., Davini, W. B., Dawe, G. B., Lord, B., and Bredt, D. S. (2019). $\alpha 6$-containing nicotinic acetylcholine receptor reconstitution involves mechanistically distinct accessory components. Cell Rep. 26, 866-874.e63. doi: 10.1016/j.celrep.2018.12.103

Gu, S., Matta, J. A., Lord, B., Harrington, A. W., Sutton, S. W., Davini, W. B., et al. (2016). Brain $\alpha 7$ nicotinic acetylcholine receptor assembly requires NACHO. Neuron 89, 948-955. doi: 10.1016/j.neuron.2016.01.018

Gu, X., Zou, Y., Su, Z., Huang, W., Zhou, Z., Arendsee, Z., et al. (2013). An update of DIVERGE software for functional divergence analysis of protein family. Mol. Biol. Evol. 30, 1713-1719. doi: 10.1093/molbev/mst069

Guinan, J. J., Jr. (2010). Cochlear efferent innervation and function. Curr. Opin. Otolaryngol. Head Neck Surg. 18, 447-453. doi: 10.1097/MOO. 0b013e32833e05d6

Hall, Z. W. (1973). Multiple forms of acetylcholinesterase and their distribution in endplate and non-endplate regions of rat diaphragm muscle. J. Neurobiol. 4 , 343-361. doi: 10.1002/neu.480040404

Harvey, V. L., Duguid, I. C., Krasel, C., and Stephens, G. J. (2006). Evidence that GABA rho subunits contribute to functional ionotropic GABA receptors in mouse cerebellar Purkinje cells. J. Physiol. 577, 127-139. doi: 10.1113/jphysiol. 2006.112482

Hassaine, G., Deluz, C., Grasso, L., Wyss, R., Tol, M. B., Hovius, R., et al. (2014). X-ray structure of the mouse serotonin 5-HT3 receptor. Nature 512, 276-281. doi: 10.1038/nature13552

Haygood, R., Babbitt, C. C., Fedrigo, O., and Wray, G. A. (2010). Contrasts between adaptive coding and noncoding changes during human evolution. Proc. Natl. Acad. Sci. U S A 107, 7853-7857. doi: 10.1073/pnas.0911249107

Hibbs, R. E., and Gouaux, E. (2011). Principles of activation and permeation in an anion-selective Cys-loop receptor. Nature 474, 54-60. doi: 10.1038/nature10139

Hiel, H., Elgoyhen, A., Drescher, D., and Morley, B. (1996). Expression of nicotinic acetylcholine receptor mRNA in the adult rat peripheral vestibular system. Brain Res. 738, 347-352. doi: 10.1016/s0006-8993(96)01046-3

Hilf, R. J., and Dutzler, R. (2008). X-ray structure of a prokaryotic pentameric ligand-gated ion channel. Nature 452, 375-379. doi: 10.1038/nature06717

Hilf, R. J., and Dutzler, R. (2009). Structure of a potentially open state of a proton-activated pentameric ligand-gated ion channel. Nature 457, 115-118. doi: $10.1038 /$ nature 07461

Hoekstra, H. E., and Coyne, J. A. (2007). The locus of evolution: evo devo and the genetics of adaptation. Evolution 61, 995-1016. doi: 10.1111/j.1558-5646.2007. 00105.x

Holbrook, J. D., Gill, C. H., Zebda, N., Spencer, J. P., Leyland, R., Rance, K. H., et al. (2009). Characterisation of 5-HT3C, 5-HT3D and 5-HT3E receptor subunits: evolution, distribution and function. J. Neurochem. 108, 384-396. doi: 10.1111/j.1471-4159.2008.05775.x 
Holden-Dye, L., Joyner, M., O'Connor, V., and Walker, R. J. (2013). Nicotinic acetylcholine receptors: a comparison of the nAChRs of Caenorhabditis elegans and parasitic nematodes. Parasitol. Int. 62, 606-615. doi: 10.1016/j.parint.2013. 03.004

Holt, J. C., Lysakowski, A., and Goldberg, J. M. (2006). Mechanisms of efferentmediated responses in the turtle posterior crista. J. Neurosci. 26, 13180-13193. doi: 10.1523/JNEUROSCI.3539-06.2006

Holt, J., Lysakowski, A., and Goldberg, J. (2011). "The efferent vestibular system," in Auditory and Vestibular Efferents, eds D. Ryugo, R. Fay and A. N. Popper (New York: Springer), 135-186.

Housley, G. D., and Ashmore, J. F. (1991). Direct measurement of the action of acetylcholine on isolated outer hair cells of the guinea pig cochlea. Proc. Biol. Sci. 244, 161-167. doi: 10.1098/rspb.1991.0065

Hudspeth, A. (1997). Mechanical amplification of stimuli by hair cells. Curr. Opin. Neurobiol. 7, 480-486. doi: 10.1016/s0959-4388(97)80026-8

Im, G. J., Moskowitz, H. S., Lehar, M., Hiel, H., and Fuchs, P. A. (2014). Synaptic calcium regulation in hair cells of the chicken basilar papilla. J. Neurosci. 34, 16688-16697. doi: 10.1523/JNEUROSCI.2615-14.2014

International Chicken Genome Sequencing Consortium. (2004). Sequence and comparative analysis of the chicken genome provide unique perspectives on vertebrate evolution. Nature 432, 695-716. doi: 10.1038/nature03154

Jacob, T. C., Moss, S. J., and Jurd, R. (2008). GABA(A) receptor trafficking and its role in the dynamic modulation of neuronal inhibition. Nat. Rev. Neurosci. 9, 331-343. doi: 10.1038/nrn2370

Jaiteh, M., Taly, A., and Hénin, J. (2016). Evolution of pentameric ligand-gated ion channels: pro-loop receptors. PLoS One 11:e0151934. doi: 10.1371/journal. pone. 0151934

Jiao, Y., Cao, Y., Zheng, Z., Liu, M., and Guo, X. (2019). Massive expansion and diversity of nicotinic acetylcholine receptors in lophotrochozoans. BMC Genomics 20:937. doi: 10.1186/s12864-019-6278-9

Johnson, S. L., Wedemeyer, C., Vetter, D. E., Adachi, R., Holley, M. C., Elgoyhen, A. B., et al. (2013). Cholinergic efferent synaptic transmission regulates the maturation of auditory hair cell ribbon synapses. Open Biol. 3:130163. doi: 10.1098/rsob.130163

Jones, A. K., Goven, D., Froger, J. A., Bantz, A., and Raymond, V. (2021). The cys-loop ligand-gated ion channel gene superfamilies of the cockroaches Blattella germanica and Periplaneta americana. Pest Manag. Sci. 77, 3787-3799. doi: $10.1002 /$ ps.6245

Jones, A. K., and Sattelle, D. B. (2004). Functional genomics of the nicotinic acetylcholine receptor gene family of the nematode, Caenorhabditis elegans. Bioessays 26, 39-49. doi: 10.1002/bies. 10377

Jones, A. K., and Sattelle, D. B. (2010). Diversity of insect nicotinic acetylcholine receptor subunits. Adv. Exp. Med. Biol. 683, 25-43. doi: 10.1007/978-1-44196445-8_3

Karlin, A. (2002). Ion channel structure: emerging structure of the nicotinic acetylcholine receptors. Nat. Rev. Neurosci. 3, 102-114. doi: 10.1038/nrn731

Karlin, A., and Akabas, M. (1995). Toward a structural basis for the function of nicotinic acetylcholine receptors and their cousins. Neuron 15, 1231-1244. doi: 10.1016/0896-6273(95)90004-7

Katz, E., and Elgoyhen, A. B. (2014). Short-term plasticity and modulation of synaptic transmission at mammalian inhibitory cholinergic olivocochlear synapses. Front. Syst. Neurosci. 8:224. doi: 10.3389/fnsys.2014.00224

Katz, E., Elgoyhen, A. B., and Fuchs, P. (2011). "Cholinergic inhibition of hair cells," in Auditory and Vestibular Efferents, eds D. K. Ryugo, R. R. Fay and A. N. Popper (New York: Springer), 103-133.

Katz, E., Elgoyhen, A. B., Gomez-Casati, M. E., Knipper, M., Vetter, D. E., Fuchs, P. A., et al. (2004). Developmental regulation of nicotinic synapses on cochlear inner hair cells. J. Neurosci. 24, 7814-7820. doi: 10.1523/JNEUROSCI. 2102-04.2004

Kearney, G., Zorrilla de San Martín, J., Vattino, L. G., Elgoyhen, A. B., Wedemeyer, C., and Katz, E. (2019). Developmental synaptic changes at the transient olivocochlear-inner hair cell synapse. J. Neurosci. 39, 3360-3375. doi: 10.1523/JNEUROSCI.2746-18.2019

Koenen, M., Peter, C., Villarroel, A., Witzemann, V., and Sakmann, B. (2005). Acetylcholine receptor channel subtype directs the innervation pattern of skeletal muscle. EMBO Rep. 6, 570-576. doi: 10.1038/sj.embor.7400429

Koperniak, T. M., Garg, B. K., Boltax, J., and Loring, R. H. (2013). Cellspecific effects on surface $\alpha 7$ nicotinic receptor expression revealed by over-expression and knockdown of rat RIC3 protein. J. Neurochem. 124, 300-309. doi: 10.1111/jnc.12095

Köppl, C. (2011a). Birds-same thing, but different? Convergent evolution in the avian and mammalian auditory systems provides informative comparative models. Hear. Res. 273, 65-71. doi: 10.1016/j.heares.2010. 03.095

Köppl, C. (2011b). "Evolution of the octavolateral efferent system," in Auditory and Vestibular Efferents, eds D. Ryugo, R. Fay and A. N. Popper (New York: Springer), 217-259.

Krashia, P., Moroni, M., Broadbent, S., Hofmann, G., Kracun, S., Beato, M., et al. (2010). Human $\alpha 3 \beta 4$ neuronal nicotinic receptors show different stoichiometry if they are expressed in Xenopus oocytes or mammalian HEK293 cells. PLoS One 5:e13611. doi: 10.1371/journal.pone.0013611

Kullberg, R. W., Zheng, Y. C., Todt, W., Owens, J. L., Fraser, S. E., and Mandel, G. (1994). Structure and expression of the nicotinic acetylcholine receptor $\beta$ subunit of Xenopus laevis. Recept. Channels 2, 23-31.

Kuryatov, A., Onksen, J., and Lindstrom, J. (2008). Roles of accessory subunits in $\alpha 4 \beta 2\left(^{*}\right)$ nicotinic receptors. Mol. Pharmacol. $74,132-143$. doi: $10.1124 / \mathrm{mol}$. 108.046789

Kweon, H. J., Gu, S., Witham, E., Dhara, M., Yu, H., Mandon, E. D., et al. (2020). NACHO engages $\mathrm{N}$-glycosylation ER chaperone pathways for $\alpha 7$ nicotinic receptor assembly. Cell Rep. 32:108025. doi: 10.1016/j.celrep.2020.108025

Landisman, C. E., and Connors, B. W. (2007). VPM and PoM nuclei of the rat somatosensory thalamus: intrinsic neuronal properties and corticothalamic feedback. Cereb. Cortex 17, 2853-2865. doi: 10.1093/cercor/ bhm025

Le Novere, N., and Changeux, J. (1995). Molecular evolution of the nicotinic acetylcholine receptor: an example of multigene family in excitable cells. J. Mol. Evol. 40, 155-172. doi: 10.1007/BF00167110

Le Novere, N., Corringer, P. J., and Changeux, J. P. (2002). The diversity of subunit composition in nAChRs: evolutionary origins, physiologic and pharmacologic consequences. J. Neurobiol. 53, 447-456. doi: 10.1002/neu.10153

Li, M., Yang, Z., Guo, H., and Dash, B. (2016). "Evolutionary relationship of nicotinic acetylcholine receptor subunits in both vertebrate and invertebrate species," in Nicotinic Acetylcholine Receptor Technologies. Neuromethods, ed M. Li (New York: Humana Press), 227-254.

Lipovsek, M., Fierro, A., Perez, E. G., Boffi, J. C., Millar, N. S., Fuchs, P., et al. (2014). Tracking the molecular evolution of calcium permeability in a nicotinic acetylcholine receptor. Mol. Biol. Evol. 31, 3250-3265. doi: 10.1093/molbev/msu258

Lipovsek, M., Im, G. J., Franchini, L. F., Pisciottano, F., Katz, E., Fuchs, P. A., et al. (2012). Phylogenetic differences in calcium permeability of the auditory hair cell cholinergic nicotinic receptor. Proc. Natl. Acad. Sci. U S A 109, 4308-4313. doi: 10.1073/pnas.1115488109

Liu, Q., Li, M., Whiteaker, P., Shi, F. D., Morley, B. J., and Lukas, R. J. (2019). Attenuation in nicotinic acetylcholine receptor $\alpha 9$ and $\alpha 10$ subunit double knock-out mice of experimental autoimmune encephalomyelitis. Biomolecules 9:827. doi: 10.3390/biom9120827

Liu, J., Wang, Z., Li, J., Xu, L., Liu, J., Feng, S., et al. (2021). A new emu genome illuminates the evolution of genome configuration and nuclear architecture of avian chromosomes. Genome Res. 31, 497-511. doi: 10.1101/gr.27 1569.120

Liu, Q., Whiteaker, P., Morley, B. J., Shi, F. D., and Lukas, R. J. (2017). Distinctive roles for $\alpha 7^{\star}$ - and $\alpha 9^{*}$-nicotinic acetylcholine receptors in inflammatory and autoimmune responses in the murine experimental autoimmune encephalomyelitis model of multiple sclerosis. Front. Cell. Neurosci. 11:287. doi: $10.3389 /$ fncel.2017.00287

Lunsford, E. T., Skandalis, D. A., and Liao, J. C. (2019). Efferent modulation of spontaneous lateral line activity during and after zebrafish motor commands. J. Neurophysiol. 122, 2438-2448. doi: 10.1152/jn.00594.2019

Macdonald, R. L., and Olsen, R. W. (1994). GABAA receptor channels. Annu. Rev. Neurosci. 17, 569-602. doi: 10.1146/annurev.ne.17.030194.003033

Mameli-Engvall, M., Evrard, A., Pons, S., Maskos, U., Svensson, T. H., Changeux, J. P., et al. (2006). Hierarchical control of dopamine neuron-firing patterns by nicotinic receptors. Neuron 50, 911-921. doi: 10.1016/j.neuron. 2006.05.007

Manley, G. A. (2000). Cochlear mechanisms from a phylogenetic viewpoint. Proc. Natl. Acad. Sci. U S A 97, 11736-11743. doi: 10.1073/pnas.97.22.11736 
Manley, G. A. (2017). Comparative auditory neuroscience: understanding the evolution and function of ears. J. Assoc. Res. Otolaryngol. 18, 1-24. doi: 10.1007/s10162-016-0579-3

Manley, G. A., and Fuchs, P. A. (2011). Recent advances in comparative hearing. Hear. Res. 273, 1-6. doi: 10.1016/j.heares.2011.01.005

Manley, G. A., and Köppl, C. (1998). Phylogenetic development of the cochlea and its innervation. Curr. Opin. Neurobiol. 8, 468-474. doi: 10.1016/s09594388(98)80033-0

Manni, L., Mackie, G. O., Caicci, F., Zaniolo, G., and Burighel, P. (2006). Coronal organ of ascidians and the evolutionary significance of secondary sensory cells in chordates. J. Comp. Neurol. 495, 363-373. doi: 10.1002/cne.20867

Marcovich, I., Moglie, M. J., Carpaneto Freixas, A. E., Trigila, A. P., Franchini, L. F., Plazas, P. V., et al. (2020). Distinct evolutionary trajectories of neuronal and hair cell nicotinic acetylcholine receptors. Mol. Biol. Evol. 37, 1070-1089. doi: 10.1093/molbev/msz290

Maricq, A. V., Peterson, A. S., Brake, A. J., Myers, R. M., and Julius, D. (1991). Primary structure and functional expression of the 5HT3 receptor, a serotonin-gated ion channel. Science 254, 432-437. doi: 10.1126/science. 1718042

Maskos, U., Molles, B. E., Pons, S., Besson, M., Guiard, B. P., Guilloux, J. P., et al. (2005). Nicotine reinforcement and cognition restored by targeted expression of nicotinic receptors. Nature 436, 103-107. doi: 10.1038/nature 03694

Matta, J. A., Gu, S., Davini, W. B., Lord, B., Siuda, E. R., Harrington, A. W., et al. (2017). NACHO mediates nicotinic acetylcholine receptor function throughout the brain. Cell Rep. 19, 688-696. doi: 10.1016/j.celrep.2017.04.008

Mazzaferro, S., Benallegue, N., Carbone, A., Gasparri, F., Vijayan, R., Biggin, P. C., et al. (2011). Additional acetylcholine (ACh) binding site at $\alpha 4 / \alpha 4$ interface of ( $\alpha 4 \beta 2) 2 \alpha 4$ nicotinic receptor influences agonist sensitivity. J. Biol. Chem. 286, 31043-31054. doi: 10.1074/jbc.M111.262014

Mazzaferro, S., Bermudez, I., and Sine, S. M. (2017). $\alpha 4 \beta 2$ nicotinic acetylcholine receptors: relationships between subunit stoichiometry and function at the single channel level. J. Biol. Chem. 292, 2729-2740. doi: 10.1074/jbc.M116. 764183

Mazzaferro, S., Gasparri, F., New, K., Alcaino, C., Faundez, M., Iturriaga Vasquez, P., et al. (2014). Non-equivalent ligand selectivity of agonist sites in $(\alpha 4 \beta 2) 2 \alpha 4$ nicotinic acetylcholine receptors: a key determinant of agonist efficacy. J. Biol. Chem. 289, 21795-21806. doi: 10.1074/jbc.M114.555136

McInturff, S., Burns, J. C., and Kelley, M. W. (2018). Characterization of spatial and temporal development of Type I and Type II hair cells in the mouse utricle using new cell-type-specific markers. Biol. Open 7:bio038083. doi: 10.1242/bio. 038083

Meier, J. C., Henneberger, C., Melnick, I., Racca, C., Harvey, R. J., Heinemann, U., et al. (2005). RNA editing produces glycine receptor $\alpha 3(\mathrm{P} 185 \mathrm{~L})$, resulting in high agonist potency. Nat. Neurosci. 8, 736-744. doi: 10.1038/nn1467

Miller, P. S., and Aricescu, A. R. (2014). Crystal structure of a human GABAA receptor. Nature 512, 270-275. doi: 10.1038/nature13293

Milligan, C. J., Buckley, N. J., Garret, M., Deuchars, J., and Deuchars, S. A. (2004). Evidence for inhibition mediated by coassembly of GABAA and GABAC receptor subunits in native central neurons. J. Neurosci. 24, 7241-7250. doi: 10.1523/JNEUROSCI.1979-04.2004

Mishina, M., Takai, T., Imoto, K., Noda, M., Takahashi, T., Numa, S., et al. (1986). Molecular distinction between fetal and adult forms of muscle acetylcholine receptor. Nature 321, 406-411. doi: 10.1038/321406a0

Mishina, M., Tobimatsu, T., Imoto, K., Tanaka, K., Fujita, Y., Fukuda, K., et al. (1985). Location of functional regions of acetylcholine receptor $\alpha$-subunit by site-directed mutagenesis. Nature 313, 364-369. doi: 10.1038/313364a0

Miyazawa, A., Fujiyoshi, Y., and Unwin, N. (2003). Structure and gating mechanism of the acetylcholine receptor pore. Nature 423, 949-955. doi: 10.1038/nature 01748

Moglie, M. J., Fuchs, P. A., Elgoyhen, A. B., and Goutman, J. D. (2018). Compartmentalization of antagonistic $\mathrm{Ca}(2+)$ signals in developing cochlear hair cells. Proc. Natl. Acad. Sci. U S A 115, E2095-E2104. doi: 10.1073/pnas. 1719077115

Moglie, M. J., Marcovich, I., Corradi, J., Carpaneto Freixas, A. E., Gallino, S., Plazas, P. V., et al. (2021a). Loss of choline agonism in the inner ear hair cell nicotinic acetylcholine receptor linked to the $\alpha 10$ subunit. Front. Mol. Neurosci. 14:639720. doi: 10.3389/fnmol.2021.639720
Moglie, M. J., Wengier, D. L., Elgoyhen, A. B., and Goutman, J. D. (2021b). Synaptic contributions to cochlear outer hair cell $\mathrm{Ca}(2+)$ dynamics. J. Neurosci. 41, 6812-6821. doi: 10.1523/JNEUROSCI.3008-20.2021

Morales-Perez, C. L., Noviello, C. M., and Hibbs, R. E. (2016). X-ray structure of the human $\alpha 4 \beta 2$ nicotinic receptor. Nature 538, 411-415. doi: 10.1038/nature19785

Morley, B., Li, H., Hiel, H., Drescher, D., and Elgoyhen, A. B. (1998). Identification of the subunits of the nicotinic cholinergic receptors in the rat cochlea using RT-PCR and in situ hybridization. Brain Res. Mol. Brain Res. 53, 78-87. doi: 10.1016/s0169-328x(97)00272-6

Morley, B. J., and Simmons, D. D. (2002). Developmental mRNA expression of the $\alpha 10$ nicotinic acetylcholine receptor subunit in the rat cochlea. Brain Res. Dev. Brain Res. 139, 87-96. doi: 10.1016/s0165-3806(02)00514-x

Morley, B. J., Whiteaker, P., and Elgoyhen, A. B. (2018). Commentary: nicotinic acetylcholine receptor $\alpha 9$ and $\alpha 10$ subunits are expressed in the brain of mice. Front. Cell. Neurosci. 12:104. doi: 10.3389/fncel.2018.00104

Moroni, M., and Bermudez, I. (2006). Stoichiometry and pharmacology of two human $\alpha 4 \beta 2$ nicotinic receptor types. J. Mol. Neurosci. 30, 95-96. doi: 10.1385/JMN:30:1:95

Moroni, M., Zwart, R., Sher, E., Cassels, B. K., and Bermudez, I. (2006). $\alpha 4 \beta 2$ nicotinic receptors with high and low acetylcholine sensitivity: pharmacology, stoichiometry and sensitivity to long-term exposure to nicotine. Mol. Pharmacol. 70, 755-768. doi: 10.1124/mol.106.023044

Moss, S. J., Beeson, D. M., Jackson, J. F., Darlison, M. G., and Barnard, E. A. (1987). Differential expression of nicotinic acetylcholine receptor genes in innervated and denervated chicken muscle. EMBO J. 6, 3917-3921.

Nelson, M. E., Kuryatov, A., Choi, C. H., Zhou, Y., and Lindstrom, J. (2003). Alternate stoichiometries of $\alpha 4 \beta 2$ nicotinic acetylcholine receptors. Mol. Pharmacol. 63, 332-341. doi: 10.1124/mol.63.2.332

Nemecz, Á., Prevost, M. S., Menny, A., and Corringer, P. J. (2016). Emerging molecular mechanisms of signal transduction in pentameric ligand-gated ion channels. Neuron 90, 452-470. doi: 10.1016/j.neuron.2016.03.032

New, K., Del Villar, S. G., Mazzaferro, S., Alcaino, C., and Bermudez, I. (2018). The fifth subunit of the $(\alpha 4 \beta 2)(2) \beta 2$ nicotinic ACh receptor modulates maximal ACh responses. Br. J. Pharmacol. 175, 1822-1837. doi: 10.1111/bph. 13905

Nguyen, V. T., Chernyavsky, A. I., Arredondo, J., Bercovich, D., Orr-Urtreger, A., Vetter, D. E., et al. (2004). Synergistic control of keratinocyte adhesion through muscarinic and nicotinic acetylcholine receptor subtypes. Exp. Cell Res. 294, 534-549. doi: 10.1016/j.yexcr.2003.12.010

Niesler, B. (2011). 5-HT(3) receptors: potential of individual isoforms for personalised therapy. Curr. Opin. Pharmacol. 11, 81-86. doi: 10.1016/j.coph. 2011.01.011

Niesler, B., Walstab, J., Combrink, S., Möller, D., Kapeller, J., Rietdorf, J., et al. (2007). Characterization of the novel human serotonin receptor subunits 5 HT3C,5-HT3D and 5-HT3E. Mol. Pharmacol. 72, 8-17. doi: 10.1124/mol.106. 032144

Nishino, A., Baba, S. A., and Okamura, Y. (2011). A mechanism for graded motor control encoded in the channel properties of the muscle ACh receptor. Proc. Natl. Acad. Sci. U S A 108, 2599-2604. doi: 10.1073/pnas.1013547108

Noda, M., Takahashi, H., Tanabe, T., Toyosato, M., Furutani, Y., Hirose, T., et al. (1982). Primary structure of $\alpha$-subunit precursor of Torpedo californica acetylcholine receptor deduced from cDNA sequence. Nature 299, 793-797. doi: 10.1038/299793a0

Oertel, J., Villmann, C., Kettenmann, H., Kirchhoff, F., and Becker, C. M. (2007). A novel glycine receptor $\beta$ subunit splice variant predicts an unorthodox transmembrane topology. Assembly into heteromeric receptor complexes. J. Biol. Chem. 282, 2798-2807. doi: 10.1074/jbc.M608941200

Olsen, R. W., and Sieghart, W. (2008). International union of pharmacology. LXX. Subtypes of $\gamma$-aminobutyric $\operatorname{acid}(\mathrm{A})$ receptors: classification on the basis of subunit composition, pharmacology and function. Update. Pharmacol. Rev. 60, 243-260. doi: 10.1124/pr.108.00505

Ortells, M., and Lunt, G. (1995). Evolutionary history of the ligandgated ion-channel superfamily of receptors. Trends Neurosci. 18, 121-127. doi: 10.1016/0166-2236(95)93887-4

Parks, X. X., Contini, D., Jordan, P. M., and Holt, J. C. (2017). Confirming a role for $\alpha 9 \mathrm{nAChRs}$ and SK potassium channels in type ii hair cells of the turtle posterior crista. Front. Cell. Neurosci. 11:356. doi: 10.3389/fncel.2017.00356 
Patrick, J., Séquéla, P., Vernino, S., Amador, M., Luetje, C., and Dani, J. A. (1993). Functional diversity of neuronal nicotinic acetylcholine receptors. Prog. Brain Res. 98, 113-120. doi: 10.1016/s0079-6123(08)62387-0

Pedersen, J. E., Bergqvist, C. A., and Larhammar, D. (2019). Evolution of vertebrate nicotinic acetylcholine receptors. BMC Evol. Biol. 19:38. doi: 10.1186/s12862018-1341-8

Peng, H., Ferris, R. L., Matthews, T., Hiel, H., Lopez-Albaitero, A., and Lustig, L. R. (2004). Characterization of the human nicotinic acetylcholine receptor subunit $\alpha(\alpha) 9$ (CHRNA9) and $\alpha(\alpha) 10$ (CHRNA10) in lymphocytes. Life Sci. 76, 263-280. doi: 10.1016/j.lfs.2004.05.031

Pichler, P., and Lagnado, L. (2020). Motor behavior selectively inhibits hair cells activated by forward motion in the lateral line of zebrafish. Curr. Biol. 30, 150-157.e3. doi: 10.1016/j.cub.2019.11.020

Pirker, S., Schwarzer, C., Wieselthaler, A., Sieghart, W., and Sperk, G. (2000). GABA(A) receptors: immunocytochemical distribution of 13 subunits in the adult rat brain. Neuroscience 101, 815-850. doi: 10.1016/s0306-4522(00)004425

Pisciottano, F., Cinalli, A. R., Stopiello, J. M., Castagna, V. C., Elgoyhen, A. B., Rubinstein, M., et al. (2019). Inner ear genes underwent positive selection and adaptation in the mammalian lineage. Mol. Biol. Evol. 36, 1653-1670. doi: 10.1093/molbev/msz077

Plazas, P. V., Savino, J., Kracun, S., Gomez-Casati, M. E., Katz, E., Parsons, C. G., et al. (2007). Inhibition of the $\alpha 9 \alpha 10$ nicotinic cholinergic receptor by neramexane, an open channel blocker of N-methyl-D-aspartate receptors. Eur. J. Pharmacol. 566, 11-19. doi: 10.1016/j.ejphar.2007.03.026

Rajendra, S., Vandenberg, R. J., Pierce, K. D., Cunningham, A. M., French, P. W., Barry, P. H., et al. (1995). The unique extracellular disulfide loop of the glycine receptor is a principal ligand binding element. EMBO J. 14, 2987-2998.

Rigon, F., Gasparini, F., Shimeld, S. M., Candiani, S., and Manni, L. (2018). Developmental signature, synaptic connectivity and neurotransmission are conserved between vertebrate hair cells and tunicate coronal cells. J. Comp. Neurol. 526, 957-971. doi: 10.1002/cne.24382

Rohmann, K. N., Wersinger, E., Braude, J. P., Pyott, S. J., and Fuchs, P. A. (2015). Activation of BK and SK channels by efferent synapses on outer hair cells in high-frequency regions of the rodent cochlea. J. Neurosci. 35, 1821-1830. doi: 10.1523/JNEUROSCI.2790-14.2015

Rosas-Ballina, M., Olofsson, P. S., Ochani, M., Valdés-Ferrer, S. I., Levine, Y. A., Reardon, C., et al. (2011). Acetylcholine-synthesizing T cells relay neural signals in a vagus nerve circuit. Science 334, 98-101. doi: 10.1126/science.1209985

Rothlin, C. V., Katz, E., Verbitsky, M., and Elgoyhen, A. B. (1999). The $\alpha 9$ nicotinic acetylcholine receptor shares pharmacological properties with type A $\gamma$ aminobutyric acid, glycine and type 3 serotonin receptors. Mol. Pharmacol. 55, 248-254. doi: 10.1124/mol.55.2.248

Rothlin, C. V., Lioudyno, M. I., Silbering, A. F., Plazas, P. V., Casati, M. E., Katz, E., et al. (2003). Direct interaction of serotonin type 3 receptor ligands with recombinant and native $\alpha 9 \alpha 10$-containing nicotinic cholinergic receptors. Mol. Pharmacol. 63, 1067-1074. doi: 10.1124/mol.63.5.1067

Roux, I., Wu, J. S., McIntosh, J. M., and Glowatzki, E. (2016). Assessment of the expression and role of the $\alpha 1$-nAChR subunit in efferent cholinergic function during the development of the mammalian cochlea. J. Neurophysiol. 116, 479-492. doi: 10.1152/jn.01038.2015

Rudolph, U., and Knoflach, F. (2011). Beyond classical benzodiazepines: novel therapeutic potential of GABAA receptor subtypes. Nat. Rev. Drug Discov. 10, 685-697. doi: 10.1038/nrd3502

Sallard, E., Letourneur, D., and Legendre, P. (2021). Electrophysiology of ionotropic GABA receptors. Cell. Mol. Life Sci. 78, 5341-5370. doi: 10.1007/s00018-021-03846-2

Sarto-Jackson, I., and Sieghart, W. (2008). Assembly of GABA(A) receptors (Review). Mol. Memb. Biol. 25, 302-310. doi: 10.1080/09687680801914516

Scheffer, D., Sage, C., Plazas, P. V., Huang, M., Wedemeyer, C., Zhang, D. S., et al. (2007). The $\alpha 1$ subunit of nicotinic acetylcholine receptors in the inner ear: transcriptional regulation by ATOH1 and co-expression with the $\gamma$ subunit in hair cells. J. Neurochem. 103, 2651-2664. doi: 10.1111/j.1471-4159.2007. 04980.x

Sciaccaluga, M., Moriconi, C., Martinello, K., Catalano, M., Bermudez, I., Stitzel, J. A., et al. (2015). Crucial role of nicotinic $\alpha 5$ subunit variants for $\mathrm{Ca} 2+$ fluxes in ventral midbrain neurons. FASEB J. 29, 3389-3398. doi: 10.1096/fj. 14-268102
Séguéla, P., Wadiche, J., Dineley-Miller, K., Dani, J. A., and Patrick, J. W. (1993). Molecular cloning, functional properties and distribution of rat brain $\alpha 7$ : a nicotinic cation channel highly permeable to calcium. J. Neurosci. 13, 596-604. doi: 10.1523/JNEUROSCI.13-02-00596.1993

Sgard, F., Charpentier, E., Bertrand, S., Walker, N., Caput, D., Graham, D., et al. (2002). A novel human nicotinic receptor subunit, $\alpha 10$, that confers functionality to the $\alpha 9$-subunit. Mol. Pharmacol. 61, 150-159. doi: 10.1124/mol. 61.1 .150

Sienknecht, U. J., Köppl, C., and Fritzsch, B. (2014). Evolution and development of hair cell polarity and efferent function in the inner ear. Brain Behav. Evol. 83, 150-161. doi: 10.1159/000357752

Simmons, D. D., Mansdorf, N. B., and Kim, J. H. (1996). Olivocochlear innervation of inner and outer hair cells during postnatal maturation: evidence for a waiting period. J. Comp. Neurol. 370, 551-562. doi: 10.1002/(SICI)10969861(19960708)370:4<551::AID-CNE10>3.0.CO;2-M

Simon, J., Wakimoto, H., Fujita, N., Lalande, M., and Barnard, E. A. (2004). Analysis of the set of GABA(A) receptor genes in the human genome. J. Biol. Chem. 279, 41422-41435. doi: 10.1074/jbc.M401354200

Skok, V. I. (2002). Nicotinic acetylcholine receptors in autonomic ganglia. Auton. Neurosci. 97, 1-11. doi: 10.1016/s1566-0702(01)00386-1

Smart, T. G., and Stephenson, F. A. (2019). A half century of $\gamma$-aminobutyric acid. Brain Neurosci. Adv. 3:2398212819858249. doi: 10.1177/2398212819858249

St-Pierre, S., Jiang, W., Roy, P., Champigny, C., LeBlanc, É., Morley, B. J., et al. (2016). Nicotinic acetylcholine receptors modulate bone marrow-derived pro-inflammatory monocyte production and survival. PLoS One 11:e0150230. doi: 10.1371/journal.pone.0150230

Sullivan, P. F., Neale, B. M., van den Oord, E., Miles, M. F., Neale, M. C., Bulik, C. M., et al. (2004). Candidate genes for nicotine dependence via linkage, epistasis and bioinformatics. Am. J. Med. Genet. B Neuropsychiatr. Genet. 126B, 23-36. doi: 10.1002/ajmg.b.20138

Tapia, L., Kuryatov, A., and Lindstrom, J. (2007). Ca2+ permeability of the $(\alpha 4) 3(\beta 2) 2$ stoichiometry greatly exceeds that of $(\alpha 4) 2(\beta 2) 3$ human acetylcholine receptors. Mol. Pharmacol. 71, 769-776. doi: 10.1124/mol.106. 030445

Tapia, J. C., Wylie, J. D., Kasthuri, N., Hayworth, K. J., Schalek, R., Berger, D. R., et al. (2012). Pervasive synaptic branch removal in the mammalian neuromuscular system at birth. Neuron 74, 816-829. doi: 10.1016/j.neuron. 2012.04.017

Tasneem, A., Iyer, L. M., Jakobsson, E., and Aravind, L. (2005). Identification of the prokaryotic ligand-gated ion channels and their implications for the mechanisms and origins of animal Cys-loop ion channels. Genome Biol. 6:R4 doi: 10.1186/gb-2004-6-1-r4

Tsunoyama, K., and Gojobori, T. (1998). Evolution of nicotinic acetylcholine receptor subunits. Mol. Biol. Evol. 15, 518-527. doi: 10.1093/oxfordjournals. molbev.a025951

Tucker, A. S. (2017). Major evolutionary transitions and innovations: the tympanic middle ear. Philos. Trans. R. Soc. Lond. B Biol. Sci. 372:20150483. doi: $10.1098 /$ rstb.2015.0483

Unwin, N. (1995). Acetylcholine receptor channel imaged in the open state. Nature 373, 37-43. doi: 10.1038/373037a0

Unwin, N. (2005). Refined structure of the nicotinic acetylcholine receptor at 4A resolution. J. Mol. Biol. 346, 967-989. doi: 10.1016/j.jmb.2004. 12.031

Valbuena, S., and Lerma, J. (2016). Non-canonical signaling, the hidden life of ligand-gated ion channels. Neuron 92, 316-329. doi: 10.1016/j.neuron.2016. 10.016

Verbitsky, M., Rothlin, C., Katz, E., and Elgoyhen, A. B. (2000). Mixed nicotinic-muscarinic properties of the a9 nicotinic cholinergic receptor. Neuropharmacology 39, 2515-2524. doi: 10.1016/s0028-3908(00)00124-6

Vetter, D. E., Katz, E., Maison, S. F., Taranda, J., Turcan, S., Ballestero, J., et al. (2007). The $\alpha 10$ nicotinic acetylcholine receptor subunit is required for normal synaptic function and integrity of the olivocochlear system. Proc. Natl. Acad. Sci. U S A 104, 20594-20599. doi: 10.1073/pnas.0708 545105

Vetter, D. E., Liberman, M. C., Mann, J., Barhanin, J., Boulter, J., Brown, M. C., et al. (1999). Role of $\alpha 9$ nicotinic ACh receptor subunits in the development and function of cochlear efferent innervation. Neuron 23, 93-103. doi: 10.1016/s0896-6273(00)80756-4 
Wang, H., Yu, M., Ochani, M., Amella, C. A., Tanovic, M., Susarla, S., et al. (2003). Nicotinic acetylcholine receptor $\alpha 7$ subunit is an essential regulator of inflammation. Nature 421, 384-388. doi: 10.1038/nature 01339

Wersinger, E., McLean, W. J., Fuchs, P. A., and Pyott, S. J. (2010). BK channels mediate cholinergic inhibition of high frequency cochlear hair cells. PLoS One 5:e13836. doi: 10.1371/journal.pone.0013836

Wessler, I., and Kirkpatrick, C. J. (2008). Acetylcholine beyond neurons: the non-neuronal cholinergic system in humans. Br. J. Pharmacol. 154, 1558-1571. doi: 10.1038/bjp.2008.185

Wessler, I., Kirkpatrick, C. J., and Racké, K. (1998). Non-neuronal acetylcholine, a locally acting molecule, widely distributed in biological systems: expression and function in humans. Pharmacol. Ther. 77, 59-79. doi: 10.1016/s01637258(97)00085-5

Whiting, P., McKernan, R. M., and Iversen, L. L. (1990). Another mechanism for creating diversity in $\gamma$-aminobutyrate type A receptors: RNA splicing directs expression of two forms of gamma 2 phosphorylation site. Proc. Natl. Acad. Sci. U S A 87, 9966-9970. doi: 10.1073/pnas.87. 24.9966

Zakrzewicz, A., Richter, K., Agné, A., Wilker, S., Siebers, K., Fink, B., et al. (2017). Canonical and novel non-canonical cholinergic agonists inhibit atp-induced release of monocytic interleukin-1 $\beta$ via different combinations of nicotinic acetylcholine receptor subunits $\alpha 7, \alpha 9$ and $\alpha 10$. Front. Cell. Neurosci. 11:189. doi: 10.3389/fncel.2017.00189

Zhang, X., Lei, B., Yuan, Y., Zhang, L., Hu, L., Jin, S., et al. (2020). Brain control of humoral immune responses amenable to behavioural modulation. Nature 581, 204-208. doi: 10.1038/s41586-020-2235-7
Zheng, J., Shen, W., He, D. Z., Long, K. B., Madison, L. D., and Dallos, P. (2000). Prestin is the motor protein of cochlear outer hair cells. Nature 405, 149-155. doi: $10.1038 / 35012009$

Zoli, M., Pistillo, F., and Gotti, C. (2015). Diversity of native nicotinic receptor subtypes in mammalian brain. Neuropharmacology 96, 302-311. doi: 10.1016/j. neuropharm.2014.11.003

Zoli, M., Pucci, S., Vilella, A., and Gotti, C. (2018). Neuronal and extraneuronal nicotinic acetylcholine receptors. Curr. Neuropharmacol. 16, 338-349. doi: 10.2174/1570159X15666170912110450

Conflict of Interest: The authors declare that the research was conducted in the absence of any commercial or financial relationships that could be construed as a potential conflict of interest.

Publisher's Note: All claims expressed in this article are solely those of the authors and do not necessarily represent those of their affiliated organizations, or those of the publisher, the editors and the reviewers. Any product that may be evaluated in this article, or claim that may be made by its manufacturer, is not guaranteed or endorsed by the publisher.

Copyright (C) 2021 Lipovsek, Marcovich and Elgoyhen. This is an open-access article distributed under the terms of the Creative Commons Attribution License (CC BY). The use, distribution or reproduction in other forums is permitted, provided the original author(s) and the copyright owner(s) are credited and that the original publication in this journal is cited, in accordance with accepted academic practice. No use, distribution or reproduction is permitted which does not comply with these terms. 